\title{
Trace Metals in Groundwater of Kumba and Environs in Cameroon
}

\section{Richard Ayuk II Akoachere ${ }^{*}$ (), Thomson Areakpoh Eyong1, Marcelle-Carole Pami Ngassam², Raymond Ndip Nkongho ${ }^{3}$, Simon Oko Okpara ${ }^{4}$}

\author{
${ }^{1}$ Department of Geology, University of Buea, Buea, Cameroon \\ ${ }^{2}$ Department of Agricultural and Environmental Engineering, Pan African University/University of Ibadan, \\ Ibadan, Nigeria \\ ${ }^{3}$ Nigeria Hydrological Services Agency (NIHSA), Abuja, Nigeria \\ ${ }^{4}$ Department of Agronomy and Applied Molecular Sciences, University of Buea, Buea, Cameroon \\ Email: *r.akoachere@ubuea.cm
}

How to cite this paper: II Akoachere, R.A., Eyong, T.A., Ngassam, M.-C.P., Nkongho, R.N. and Okpara, S.O. (2019) Trace Metals in Groundwater of Kumba and Environs in Cameroon. Open Access Library Journal, 6: e5824.

https://doi.org/10.4236/oalib.1105824

Received: September 30, 2019

Accepted: October 20, 2019

Published: October 23, 2019

Copyright (ङ 2019 by author(s) and Open Access Library Inc.

This work is licensed under the Creative Commons Attribution International License (CC BY 4.0).

http://creativecommons.org/licenses/by/4.0/

\begin{abstract}
Kumba and environs situate between longitudes 9.24E - 9.5E and latitudes $4.44 \mathrm{~N}-4.7 \mathrm{~N}$, is the economic capital of the Southwest Region-Cameroon. It is located along the Cameroon Line at northwestern edge of the Douala Basin. The inhabitants depend mostly on groundwater through springs, handdug wells and boreholes. In this area like in most of Cameroon and Africa, water from groundwater sources (springs, wells and boreholes) is not treated. Often, it is given minimal or cosmetic periodic treatment if at all. Although the concentrations of trace metals in groundwater affects its safety and acceptability, testing for trace metals is less common and typically occurs mostly when a specific risk has been identified. This could be attributed to the high cost of analysis and lack of technological know-how. In addition to this, testing and monitoring of groundwater is not carried out most of the time and whenever it is done, only major cations and anions are analyzed. Due to the absence of treatment and testing of groundwater before drinking in Kumba and environs, there is a need to evaluate the trace metal content. The study had 21 groundwater samples analyzed using Inductively Coupled Plasma Mass Spectroscopy. Field measurement of physicochemical parameters was determined. R-mode statistical analysis; Pearson's Correlation Analysis (PCA) together with Hierarchical Cluster Analysis (HCA) between the trace metals and the physico-chemical parameters was carried out. Ten indices were determined: Four trace metal hazard indices: the average daily dose ADD, carcinogenic risks $\mathrm{CR}$ and the non-carcinogenic risk hazard quotient HQ which yields the hazard indices HI, and six trace metal pollution indices: Degree of contamination (DC), Enrichment factor (EF), Ecological risk index (Er), Po-
\end{abstract}


tential ecological risk index (RI), Pollution load index (PLI) and Geo-accumulation index (Igeo). The general trend of mean trace metal concentration in the groundwater is in the order of: $\mathrm{Mn}>\mathrm{Fe}>\mathrm{Ba}>\mathrm{Sr}>\mathrm{Zn}>\mathrm{Ni}>\mathrm{Cu}>$ $\mathrm{Co}>\mathrm{Pb}>\mathrm{Li}>\mathrm{Cr}>\mathrm{V}>\mathrm{As}>\mathrm{Cd}$. HCA distinguishes two clusters based on spatial similarities and dissimilarities. Cluster one; (01) element Ba; soluble; Cluster two (13) non soluble elements divided into three classes; class one (06) As, Cd, V, Li, Pb, and Cr; less enriched. Class two (03) $\mathrm{Co}, \mathrm{Cu}, \mathrm{Ni}$ and $\mathrm{Zn}$; enriched; Class two (04) $\mathrm{Zn}, \mathrm{Sr}, \mathrm{Fe}$ and $\mathrm{Mn}$; more enriched. Values of pollution indices range as follows; DC (-13.53 to 12.1), EF (1.15 - 874.13), Er (-29.68 to -0.97$)$, RI ( -61.06 to -43.03$)$, PLI ( $-0.01-0.05)$, Igeo (7E-08 287). Almost all are below the acceptable guideline values. While values of groundwater hazard indices range as follows; ADD (1.01E-06 - 0.05), CR (8.5E-06 - 0.018), HQ (3.3E-04 - 1.59) and HI (0.07 - 1.59). The groundwater hazard indices: ADD and CR are less than 1 in the categories of insignificant pollution health hazard, are below the acceptable guideline values whereas HQ and HI are above 1, likely to pose health hazards. Igeo values indicate groundwater is Unpolluted to moderately polluted by $\mathrm{Pb}, \mathrm{V}, \mathrm{Cr}, \mathrm{Co}$, As, Cd, $\mathrm{Pb}$; while it is Extremely polluted by $\mathrm{Mn}, \mathrm{Fe}, \mathrm{Ni}, \mathrm{Cu}, \mathrm{Sr}, \mathrm{Zn}, \mathrm{Ba}$. The enrichment factors show that the sources of the trace metals are from geogenic and anthropogenic processes. $\mathrm{Ba}$ and Co are enriched although they fall below the hazard risk values; this shows they have pollution potential that could be attributed to weathering and agricultural wastes. The severity of metal toxicity is governed by several factors, such as dose, nutrition, age, and even life style. Therefore, these low trends might not guarantee the complete absence of human health risks. Generally, from risk assessment on trace metals using risk indices in the analyzed groundwater samples might not cause any health risk. However, due to an increasing level of environmental pollution that might be imposed by increasing human activity in this area, groundwater sources might become a potential sink of contaminants; this is significant reason that makes constant monitoring, implementation and treatment of groundwater for drinking purposes necessary.

\section{Subject Areas}

Environmental Sciences

\section{Keywords}

Health-Hazard-Indices, Pollution Risks-Indices Trace-Metal, HCA, PCA, Kumba, Cameroon

\section{Introduction}

Kumba and environs situates between longitudes 9.24E - 9.5E and latitudes $4.44 \mathrm{~N}-4.7 \mathrm{~N}$ Figure 1; is the administrative headquarters of Meme Division and economic capital of Southwest Region of Cameroon. It is at the center of one of the largest cocoa cash crop producing areas in the country. 


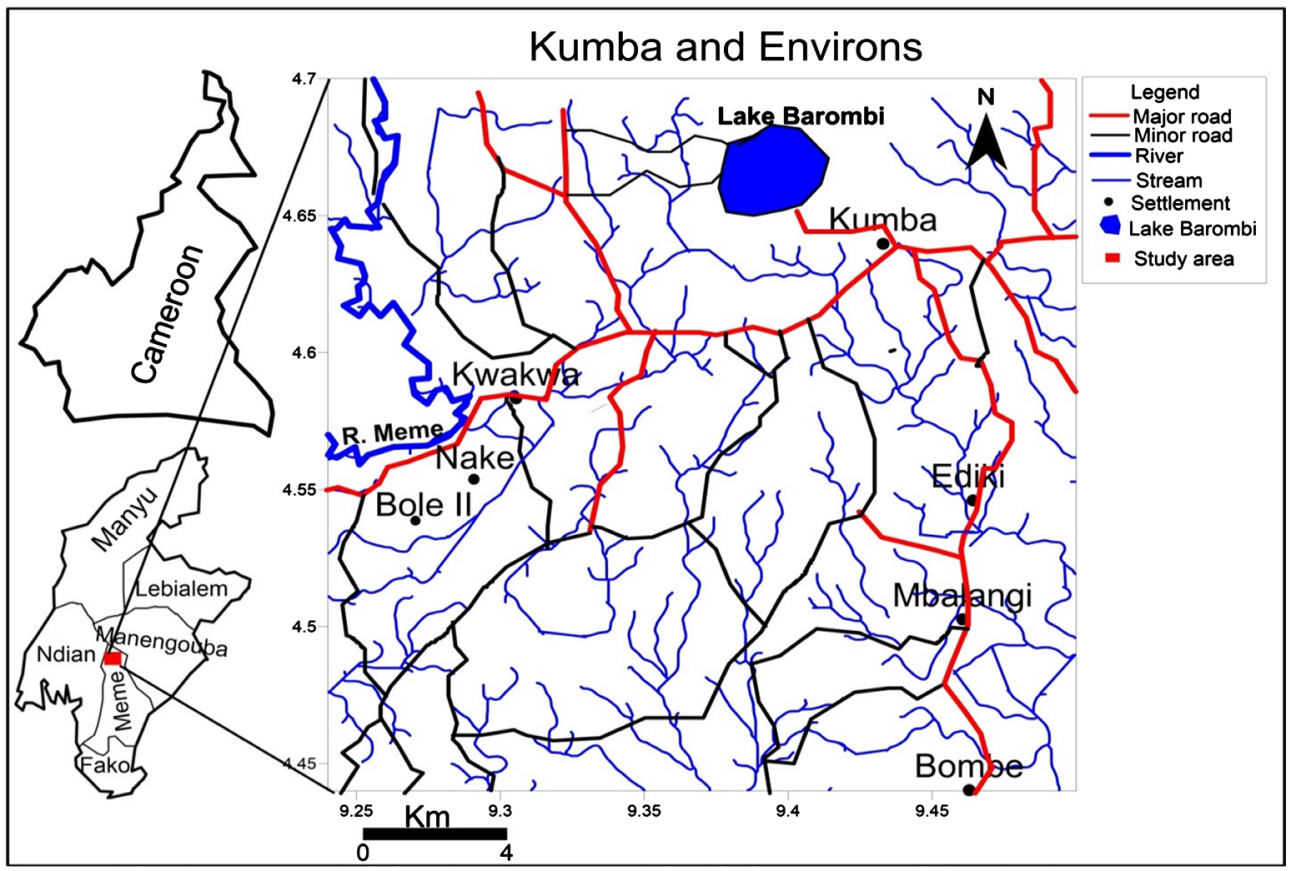

Figure 1. Location map for measurements and sample collection in Kumba and environs.

This area is an agro-industrial zone of cocoa production which is exported and dependent on groundwater. The assessment of trace metal quality of springs, dug wells and borehole water exploited for consumption by more than $90 \%$ of inhabitants of this area is sparse. Therefore a series of health risks and pollution risks associated with elevated trace metals concentrations in groundwater may arise if the trace metal concentrations of groundwater in this area is high [1].

Trace metals are chemical components found in low concentrations, in mass fractions of ppm or less, in water, organisms and soil [2]. Some trace metals are essential as micronutrients $\mathrm{Cu}, \mathrm{Fe}, \mathrm{Mn}, \mathrm{Ni}$ and $\mathrm{Zn}$ for life processes in plants and microorganisms, while others $\mathrm{Cd}, \mathrm{Cr}$ and $\mathrm{Pb}$ have no known physiological activity, but are proven detrimental beyond a certain limit which is very much narrow for some elements like $\mathrm{Cd} 0.01 \mathrm{mg} / \mathrm{L}, \mathrm{Pb} 0.10 \mathrm{mg} / \mathrm{L}$ and $\mathrm{Cu} 0.050 \mathrm{mg} / \mathrm{L}$ [3]. These toxic metals, unlike some organic substances, are not metabolically degradable and have the tendency to bio-accumulate in tissues of living organisms over time which can cause death or serious health threats [2]. The presence of trace metal species in groundwater can be of geogenic or anthropogenic origin. Natural or geogenic contamination occurs when the weathering of minerals in rocks results in the entry of heavy metals into the environments and water bodies are retained in the groundwater/soil and do not readily leach out; accumulate through geological processes, enter the food chain through ingestion and ultimately pose a threat to humans, animals and plants. By ion exchange, precipitation, dissolution or mixing, trace metal ions contained in the rocks are introduced into the water. These metals exist in water as colloidal, particulate and dissolved species. Anthropogenic contamination occurs through the development of industrial agriculture, mining, smelting and other industrial activities. 
Metallic elements have a significant role in increasing the degradation of water quality through human activities; industrial-household wastes, thermal power plants, mining, exhaust emissions, application of fertilizers, pesticides and insecticides. Trace metals pose a severe threat to human and environmental health since these elements are toxic at low concentrations and pollution caused by these heavy metals is long-term and irreversible; cumulative. Trace metals are increasingly being found in groundwater sources. The exposure to trace metal contamination and associated health risk levels of the population in AkwaMundemba has not been investigated hence; the quantification of trace metals for suitability of the groundwater resources for drinking, domestic and agroindustrial uses is of public health and scientific concern. It has been recognized for many years that the concentrations of metals found in coastal areas, whether they are in the dissolved or particulate phase may be derived from a variety of anthropogenic and natural sources. In most circumstances, the major part of the anthropogenic metal load in the marine sediments and organisms has a terrestrial source from mining and intensive aquaculture and municipal wastewaters, untreated effluents, harbor activities, urban and agricultural runoff along major rivers, estuaries and bays. These elements are: Antimony, Arsenic, Boron Barium, Bromine, Cadmium, Cesium, Chloride, Cobalt, Copper, Fluoride Iodine, Iron, Lead, Lithium, Manganese, Mercury, Molybdenum, Nickel, Phosphorus, Rubidium, Selenium, Strontium, Uranium, Vanadium and Zinc.

The study aims to improved knowledge on the occurrence of trace metals in groundwater in Kumba and environs, which will:

- Provide better information on concentration ranges in groundwater.

- Act as basis for future regulations on trace metals in drinking water from this area.

- Provide estimates of the contribution of groundwater to overall trace metal intake.

- Provide baseline on trace metals in the groundwater if challenges arise in the future.

- Estimate the health hazard and pollution indices of trace metals in groundwater.

\subsection{Climate}

Kumba generally has a hot and humid equatorial climate with two seasons: a short dry season of about 4 months (December to March) and a long rainy season (April to November). Annual rainfall ranges from $2298 \mathrm{~mm}$ to $3400 \mathrm{~mm}$. The average annual temperature is approximately $27^{\circ} \mathrm{C}$.

\subsection{Vegetation}

Kumba is located in the tropical rainforest with vegetation that varies from savannah to forest (around Lake Barombi Mbo). The evergreen and semi-deciduous forests contain economically important tree species (iroko, mahogany, obeche, 
ebony, padouk, tiama, framire, sapelline, makore and bobinga, etc.). The herbaceous layer is dominated by Pennisetum, purpureum and Imperata cylindrica with a ligneous cover that is heavily affected by human activity. The river valleys are covered with Indian bamboo (Bambousa species) whose stems are used for handicraft activities. Deforestation is the main cause of environmental degradation in Kumba. It arises from human activities, especially inappropriate farming practices (shifting cultivation), over grazing, bushfires, poaching and illegal logging.

\subsection{Geology}

Kumba is located in the Kumba Plain, a graben intercalated between the stratovolcanoes of Mt Cameroon and Mts Rumpi, at the northwestern edge of the Douala Basin as in Figure 2. The Cameroon Line (CL) is an alignment of Tertiary-to-Recent alkaline volcanoes, plutons and grabens extending over more than $1600 \mathrm{~km}$ stretching from the Atlantic oceanic island of Annobon through the Gulf of Guinea and within the African continent. The Douala basin probably formed from a Precambrian cratonisation, granitisation and sedimentation phase followed by the Pan-African orogenesis, the Afro-Brazilian depression (the site of the future Cameroon Atlantic basin) with epi-continental sedimentation which may have begun during the lower Cretaceous, discordant Cretaceous to Pliocene sediments on the Precambrian Pan-African basement and covered in

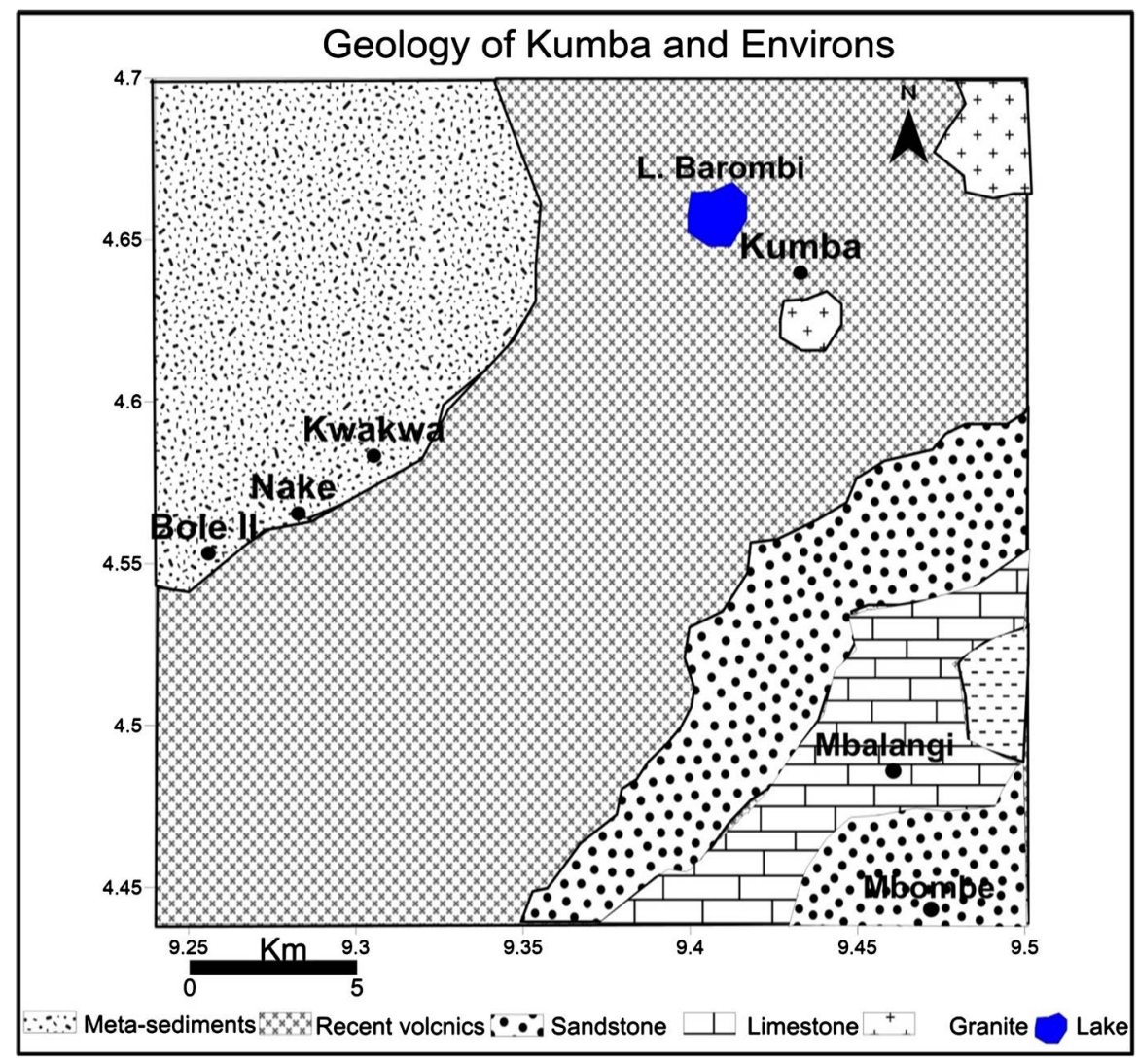

Figure 2. Geologic map of study area made up of four rock types; metasediments, recent volcanics, sandstones, limestone and granites. 
some areas by Miocene sedimentation and volcanism. The geology of the Kumba Plain (Kumba Volcanic Field) is controlled by three main volcanic activities (which probably occurred between the Eocene and $1 \mathrm{Ma}$ ago). These include: old basaltic lavas covering the entire plain; cinder cones and phreatomagmatic units; and short vesicular basaltic lava flow.

There are 4 maars in the Kumba Plain. These include: the Barombi Mbo, Barombi Koto, Mbwadong and Dissoni Maars, with the first two occupied by Lakes Barombi Mbo and Lake Barombi Koto. Based on the composite fragments contained in the Barombi Mbo Maar (BMM) pyroclastic deposits, it is likely that the maar cuts through a geological succession composed by granite gneissic formation, sandstones, and basaltic lava flows; the same formations that make up the Kumba volcanic field.

Volcanic formations of the plain have been emplaced over Pan African metamorphic formations intruded by granitoids and locally covered by Cretaceous continental sandstones. They commonly enclose mantle peridotite xenoliths [4].

\subsection{Hydrogeology}

Weathered basement (regolith), fractured-gneiss, basalts, pyroclastics and recent alluvium are the aquiferous formations in the area. Saturated hydraulic conductivities of the aquiferous formations range from $2.88 \mathrm{E}-08$ to $1.60 \mathrm{E}-06 \mathrm{~m} / \mathrm{d}$ [5], groundwater velocities from $1.96 \mathrm{E}+01$ to $6.34 \mathrm{E}+02 \mathrm{~m} / \mathrm{d}$ [4], first estimates of well yields from $4.6 \mathrm{E}-01$ to $2.28 \mathrm{E}+01 \mathrm{~m} / \mathrm{d}$ and the hydraulic conductivities of the vadose zone from $7.96 \mathrm{E}+02$ to $3.27 \mathrm{E}+04 \mathrm{~m} / \mathrm{d}$. and stream discharges $1.79 \mathrm{E}+05$ to $9.13 \mathrm{E}+05 \mathrm{~m}^{3} / \mathrm{d}[6]$.

Prior to sampling, the pre-cleaned sample bottles were rinsed with the sample water. The well water was withdrawn with the use of a $50 \mathrm{ml}$ syringe, and then filtered through the $0.2 \mu \mathrm{m}$ mixed cellulose ester filter into $50 \mathrm{ml}$ high-density polyethylene HDPE containers. The sample was preserved by acidifying to $\mathrm{pH}<$ 2 by adding nitric acid and sealed using a permanent tape. The samples were labelled and put into the sample bottle collection bag. The filtered groundwater samples were later shipped to the Activation laboratory in Canada for trace metal analysis by Inductive Coupled Plasma Mass Spectrometer ICP-MS.

\section{Materials and Methods}

\subsection{Sample Collection, Pre-Treatment and Chemical Analysis}

Twenty one samples were collected from 21 pre-selected wells, boreholes and springs. Site selection was based on spatial distribution of the wells, boreholes, springs and population. At each site, groundwater temperature, electrical conductivity, total dissolve solids and $\mathrm{pH}$ value were measured in situ, using portable field $\mathrm{pH}, \mathrm{EC}$ and TDS meters as shown in Table 1.

\subsection{Hazard Identification}

It involves the identification of the chemical of concern and documenting its 
toxic effects on human beings after field mapping. It also involves the characterization of potential contaminants and their relative mobilities [7] as shown in Table 2.

\subsection{Exposure Assessment}

This is the process of measuring or estimating the intensity, frequency and

Table 1. Field Equipment, Softwares, their specifications and functions used in the study.

\begin{tabular}{|c|c|c|}
\hline Equipment/Softwares & Specifications & Functions \\
\hline Bike & Commercial Bikes (Bensikin) & To transport fieldworkers to wells \\
\hline GPS & GARMIN GPSMAP 60 csx & To measure longitude, latitude and elevation of wells \\
\hline EC Meter & Hanna Hi 98304/Hi98303 & To measure Electrical Conductivity of water. \\
\hline $\mathrm{pH}$ Meter & Hanna Hi 98127/Hi98107 & To measure $\mathrm{pH}$ of water. \\
\hline Measuring Tape & Weighted Measuring Tape & Measurement of well diameter and depth. \\
\hline Digital Thermometer & Extech $39240\left(-50^{\circ} \mathrm{C}\right.$ To $\left.200^{\circ} \mathrm{C}\right)$ & To measure water temperature \\
\hline Total Dissolved Solid & Hanna HI 96301 & To measure Total dissolved solids \\
\hline Water sampler & Gallenkampf $500 \mathrm{ml}$ & To collect water sample from well \\
\hline Syringe & $50 \mathrm{Ml}, 100 \mathrm{Ml}$ Polystyrene & Acidification and filtration of sample \\
\hline Nitric acid & 98\% Pure Nitric Acid & Sample preservation by acidifying to $\mathrm{pH}<2$ \\
\hline Filter & Cellulose Ester Filter $0.2 \mu \mathrm{m}$ & Filtration of sample \\
\hline Sample bottles & Polyethylene (HDPE) $50 \mathrm{ml}$ & To hold sample for onward transmission to laboratory \\
\hline Sealing Tape & Permanent Tape and marker & Sealing of sample bottle and labeling for the laboratory \\
\hline IBM SPSS Statistics & Version 24.0 & Statistical analysis for PCA \\
\hline Global Mapper & Version 11 & GIS Geolocation of wells \\
\hline Surfer Golden Software & Version 12 & GIS plotting contours for spatial distribution \\
\hline
\end{tabular}

Table 2. Trace metals and their effects [2].

\begin{tabular}{cl}
\hline Component & Toxicity effects \\
\hline $\mathrm{Zn}$ & Zinc suppresses copper and iron intake causing peripheral neuropathy. \\
$\mathrm{Co}$ & Active in vitamin $\mathrm{B} 12$ and in chemical reactions. Excess causes hearth failures. \\
$\mathrm{Cu}$ & Excess leads to acute gastrointestinal problems \\
$\mathrm{Cr}$ & Excess may result in renal failures. Excess of $\mathrm{Cr}^{+6}$ is carcinogenic. \\
$\mathrm{Mn}$ & Manganese toxicity result in neurological disorder; manganism, with symptoms of tremors \\
$\mathrm{Cd}$ & Cadmium compounds are known human carcinogens. \\
$\mathrm{V}$ & Vanadium causes albumin in urine \\
$\mathrm{Ni}$ & Nickel is carcinogenic and causes neurological deficits \\
$\mathrm{As}$ & Arsenic causes cancer of the skin, lungs, liver and bladder. \\
$\mathrm{Sb}$ & Antimony causes gastrointestinal problems, kidney damage or liver damage \\
$\mathrm{Al}$ & Aluminium causes neurotoxicity. \\
$\mathrm{Pb}$ & Lead is a carcinogen affecting every organ and system in the body. \\
\hline
\end{tabular}


duration of human exposures to an environmental agent [7]. The main exposure pathway taken into consideration in this study was intake of the metals through water consumption. The daily environmental exposures to metals were assessed for carcinogenic and non-carcinogenic elements.

The intake of metals through ingestion of groundwater were calculated using Equation (1) [8].

$$
\mathrm{ADD}=\frac{\mathrm{C} \cdot \mathrm{IR} \cdot \mathrm{ED} \cdot \mathrm{EF}}{\mathrm{BW} \cdot \mathrm{AT} \cdot 360}
$$

where:

ADDs is Exposure duration (mg/kg-day) - The Average Daily Dose (ADD) of the contaminant through water pathway indicates the quantity of chemical substance ingested per kilogram of body weight per day.

$\mathrm{C}$ is Concentration of contaminant in the environmental media (e.g., $\mu \mathrm{g} / \mathrm{L}$, $\mathrm{mg} / \mathrm{L})$.

IR is Ingestion rate per unit time (e.g., $\mathrm{mg} /$ day or L/day).

EF is Exposure frequency (day/year).

ED is Exposure duration (years).

$\mathrm{BW}$ is Body weight of receptor $(\mathrm{kg})$.

AT is Averaging time = life expectancy (years) 365 is the conversion factor from years to days.

For non-carcinogenic effects, $\mathrm{AT}=\mathrm{ED}$ in days; carcinogenic effect, $\mathrm{AT}=70$ years or 25,550 days [8].

\subsection{Dose-Response/Toxicity Assessment}

This is the quantitative relationship that indicates the contaminants degree of toxicity to exposed species. It also involves the identification of the toxicity criteria used to evaluate human health risk associated with the chemical of concern in the study area. The amount of chemical that can affected human health is estimated. The Reference Dose RfD is used for non-carcinogen risk.

\subsection{Risk Characterization}

This is the final phase of the risk assessment process. In this phase, cumulative exposure and dose-response assessments are integrated to yield probabilities of effects occurring in human beings under specific exposure conditions and time scales. Also incorporated is information from hazard identification, exposure assessment, toxicity assessment and risk estimation to evaluate the potential risk to residents.

\subsection{Carcinogenic Risk Assessment}

Carcinogenic risks was determined by calculating the potential of an individual to develop cancer as a result of cumulative exposure to each potential carcinogen over a lifetime. For carcinogen, identified by a weight-of-evidence classification of the chemical [9]. 
The estimated daily dose and the cancer slope factor are multiplied together to find the lifetime cancer risk posed by the chemical. Cancer slope factors are estimates of carcinogenic potency and were used to relate estimated daily dose of the trace metal over a lifetime exposure to the lifetime probability of excess tumors Equation (2) [9] [10] [11].

$$
\mathrm{CR}=\mathrm{ADD} \cdot \mathrm{SF}
$$

CR is the excess probability of developing cancer over a lifetime as a result of exposure to a contaminant or carcinogenic risk. It is unit less; SF is the slope factor of the contaminant $[\mathrm{mg} / \mathrm{kg} / \mathrm{d}]^{-1}$.

\subsection{Non Carcinogenic Risk Assesment}

Non-carcinogenic hazards are characterized by the hazard quotient (HQ). HQ is a unitless number that is expressed as the probability of an individual suffering an adverse effect. To estimate noncarcinogenic risk, the hazard quotient (HQ) was calculated using Equation (3) [12].

$$
\mathrm{HQ}=\frac{\mathrm{ADD}}{\mathrm{RfD}},
$$

$\mathrm{RfD}$ is the reference dose $\mathrm{mg} / \mathrm{kg} / \mathrm{d}$. It represents a toxicity index of a daily exposure to the population in comparison to a safe level of exposure orally over a lifetime [13].

\subsection{Harzard Index (HI)}

It is the toxic risks due to all the potentially hazardous substances present in the same media simultaneously [14]. Since more than one toxicant is evaluated, the interactions of all the toxicants were considered and assumed to be cumulative. Thus, the HI was calculated by summing all the HQ for all toxicants, Equation (4) [12].

$$
\mathrm{HI}=\sum_{i=1}^{n} \mathrm{HQ}_{i}
$$

\subsection{Pollution Evaluation Indices}

Generally, pollution indices are estimated for a specific use of the water under consideration. The trace metal degree of contamination (DC), enrichment factor (EF), ecological risk index (Er), potential ecological risk index (RI), pollution load index (PLI) and geo-accumulation index (Igeo) were used to evaluate the pollution potential of the study area (Table 3 ).

\section{Results and Discussion}

\subsection{Physicochemical Parameters}

The physicochemical parameters groundwater in the study area: temperature, $\mathrm{pH}, \mathrm{EC}$ and TDS were evaluated as shown in Table 4.

\subsection{Water Level Fluctuations}

Depth-to static water level $(\mathrm{m})$ of groundwater ranged from: $0.2-6.2 \mathrm{~m}$ as in 
Table 3. Formulae for calculation of pollution indices.

\begin{tabular}{ccc}
\hline Trace element pollution indices & Formulae & Reference \\
\hline Degree of Contamination & $\mathrm{DC}=\sum_{i=1}^{n} C_{f}^{i}$ & (Edet and Offiong, 2002) [15] \\
Enrichment factor & $\mathrm{ER}=\frac{(\mathrm{Ci} / \mathrm{Cie}) \text { sample }}{(\mathrm{Ci} / \mathrm{Cie}) \text { background }}$ & (Zhang et al., 2007) [16] \\
Ecological risk factor & $\mathrm{Eir}=\mathrm{Tri} \times \mathrm{Cfi}$ & Håkanson, (1980) [17] \\
Ecological risk index & $\mathrm{RIi}=\sum_{i=1}^{n} E_{r}^{i}$ & Håkanson (1980) [17] \\
pollution load index & $\mathrm{PLI}=\sqrt[n]{C_{f 1} \times C_{f 2} \times \cdots \times C_{f n}}$ & (Harikumar et al., 2009) [18] \\
Geo-accumulation index & $\mathrm{Igeo}=\log 2[\mathrm{Ci} /(1.5 \mathrm{Cri})]$ & (Ji et al., 2008) [19] \\
\hline
\end{tabular}

Table 4. Field determined physicochemical parameters; electrical conductivity (EC), pH, total dissolved solids (TDS) and temperature of groundwater in study area.

\begin{tabular}{cccc}
\hline Parameter & Min & Max & Mean \\
\hline $\mathrm{T}\left({ }^{\circ} \mathrm{C}\right)$ & 26.7 & 29.1 & 27.7 \\
$\mathrm{PH}$ & 2.3 & 6.4 & 5.1 \\
$\mathrm{EC}(\mathrm{mS} / \mathrm{cm})$ & 1.8 & 50.1 & 17.7 \\
$\mathrm{TDS}(\mathrm{mg} / \mathrm{L})$ & 1.2 & 33.6 & 11.9 \\
\hline
\end{tabular}

Figure 3. Areas with low depths to static water levels such as; Kumba, Ediki, Bombe and Kwakwa are susceptible to pollution if the wells are not appropriately constructed and protected.

\subsection{Groundwater Flow Direction}

Groundwater flows towards the Southwestern and Northwestern parts of the study area which could probably be a recharge zone as in Figure 4 .

\subsection{Temperature}

Temperature values of groundwater ranged from: $26.7^{\circ} \mathrm{C}-29.1^{\circ} \mathrm{C}$ as seen in Figure 5. The temperature variation is similar in the different areas, suggesting a single aquifer since groundwater in the same aquifers have similar parameter values and temperature is one of them.

\section{5. $\mathrm{pH}$}

The $\mathrm{pH}$ value of most of the groundwater samples in the study area ranged from 2.3 - 6.4 as in Figure 6. The value of $\mathrm{pH}$ of a water sample is recognized as an index of classifying groundwater as acidic $<5.5$, slightly acidic $5.5-6.5$, neutral $6.5-7.5$, slightly alkaline $7.5-8$, moderately alkaline $8-9$ and alkaline $>9$. This clearly shows that the groundwater in the study area is acidic to slightly acidic.

\subsection{Electrical Conductivity}

The EC ranged from $1.8-50.1 \mathrm{mS} / \mathrm{m}$ as in Figure 7. The low electrical conductivity 


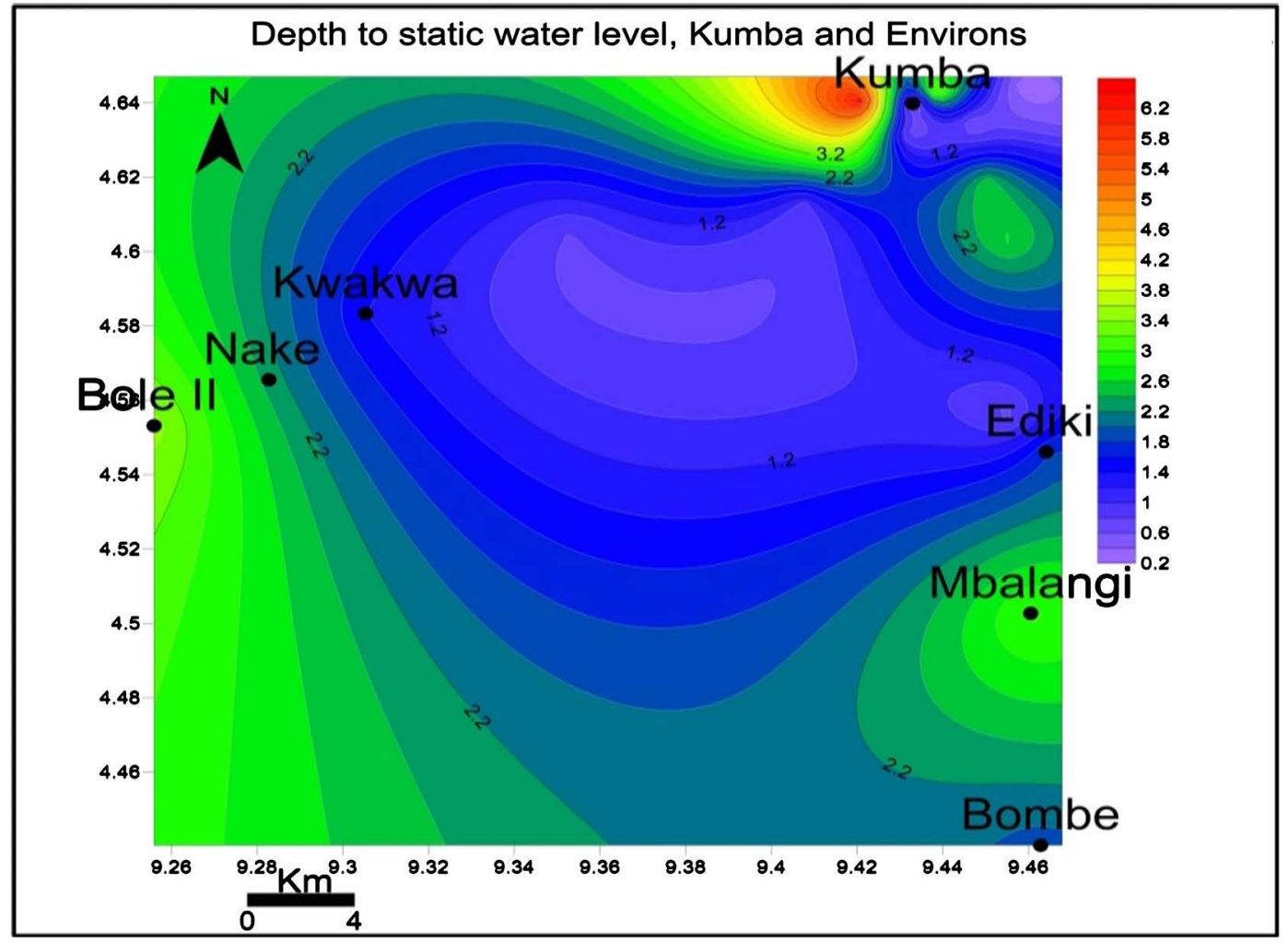

Figure 3. Depth to static water level; high values are at Mbalangi, Bole II and Nake whereas low values are at Kumba, Ediki, Bombe and Kwakwa.

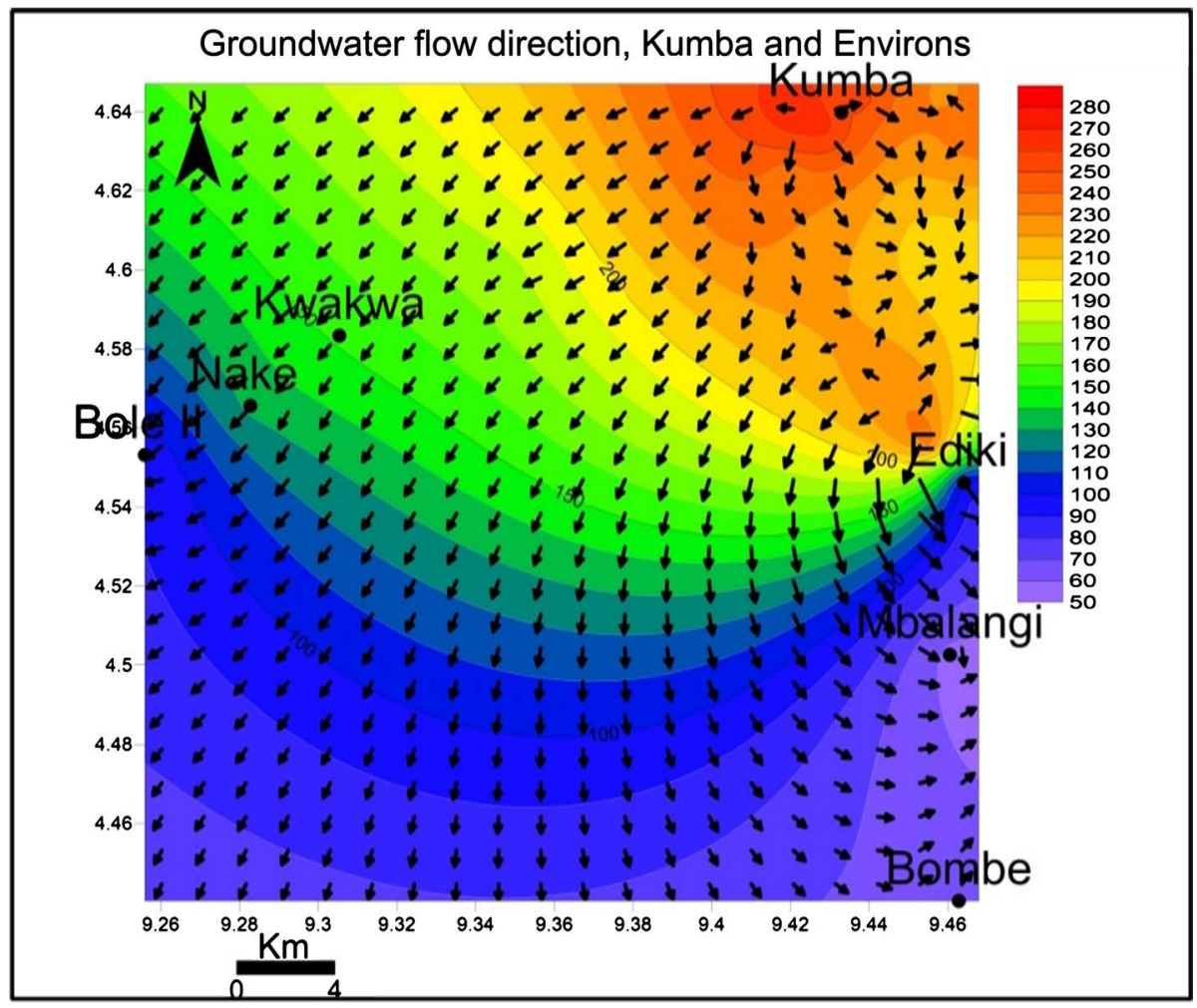

Figure 4. Groundwater flow direction in study area indicating that water flows towards the Southwestern and Northeastern parts of the study area. 


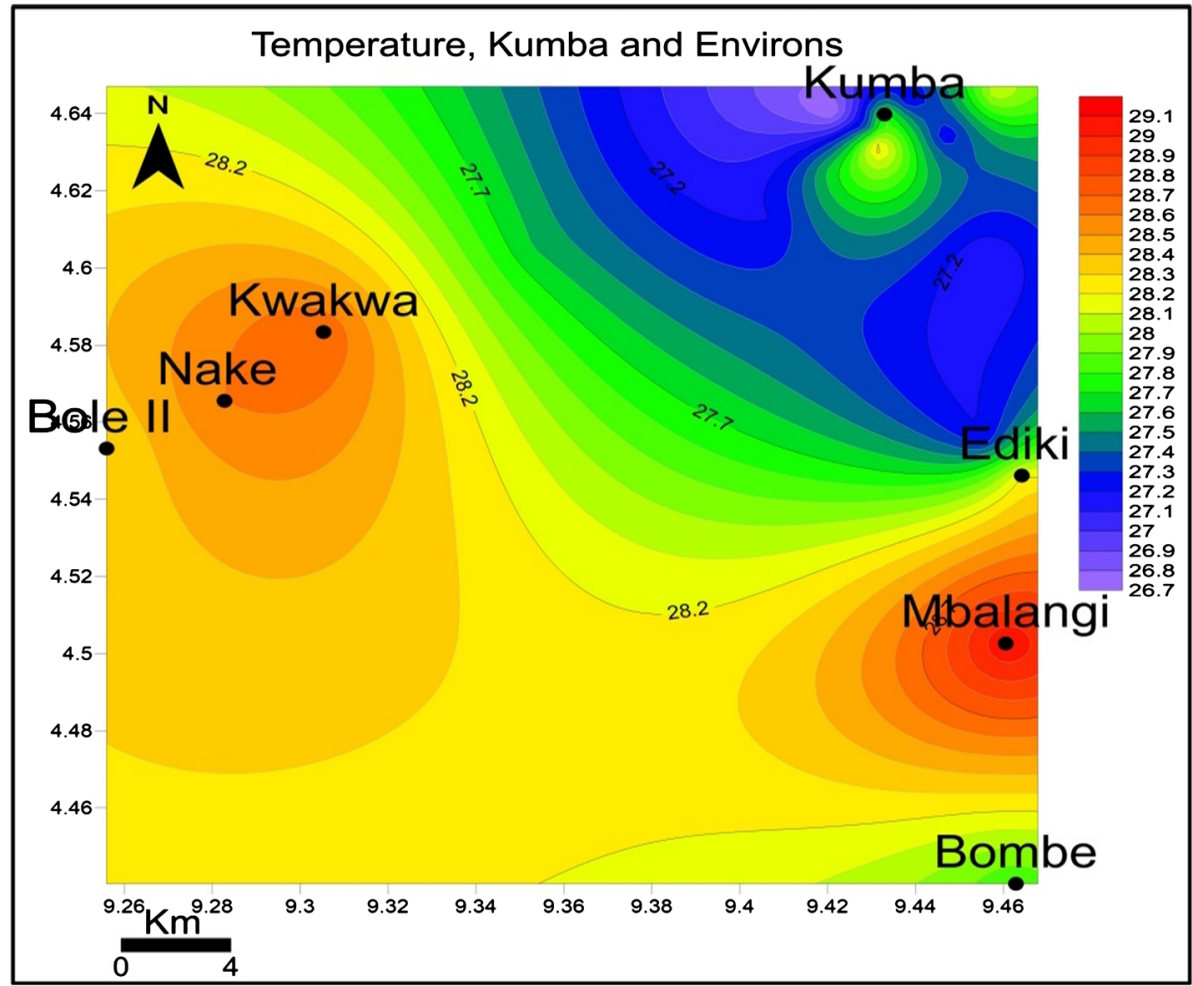

Figure 5. Spatial variation of groundwater temperatures; Temperatures are generally higher at Mbalangi, Ediki, Bole II, Kwakwa and Bombe while low values are at Kumba.

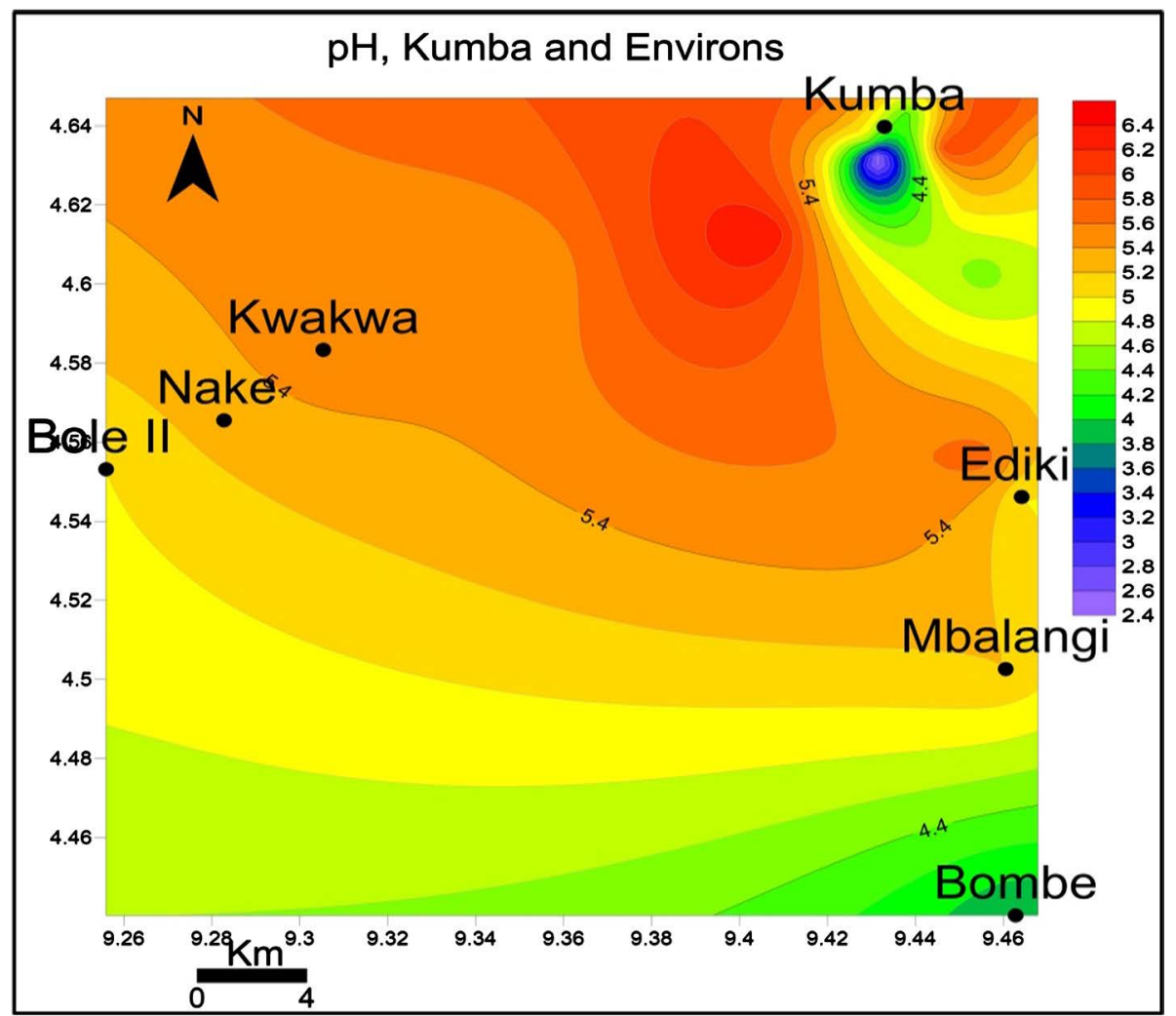

Figure 6. Spatial variation of $\mathrm{pH}$; High $\mathrm{pH}$ values are at Mbalangi, Bole II, Nake, Kwakwa and Ediki while low values are at Kumba and Bombe. 


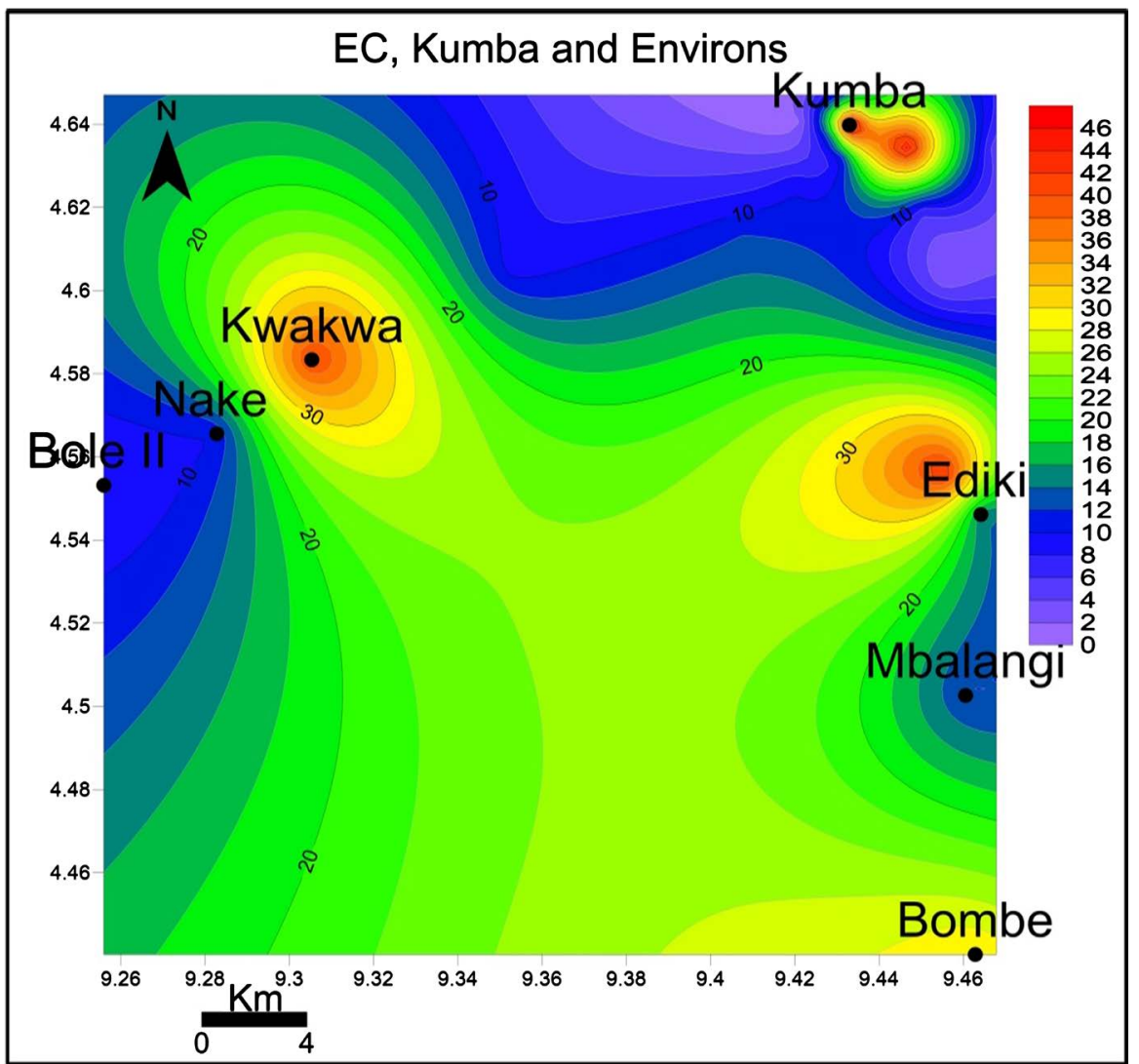

Figure 7. Spatial variation of Electrical Conductivities $(\mathrm{mS} / \mathrm{m})$; EC is at maximum at Kumba, Kwakwa, Ediki and Bombe while minimum values are at Nake, Bole II, and Mbalangi.

is due to less solute concentration in groundwater.

\subsection{Total Dissolved Solids}

The total dissolved solids ranged from $1.2-33.6 \mathrm{mg} / \mathrm{L}$ as in Figure 8. These TDS values are $<500 \mathrm{mg} / \mathrm{L}$ thus indicating that the water is fresh.

\subsection{Trace Metal Concentration}

The results for twenty one samples of trace metal analysis ICP-MS are presented in Table 5. The concentrations of fourteen trace metals; $\mathrm{Mn}, \mathrm{Fe}, \mathrm{Ba}, \mathrm{Sr}, \mathrm{Zn}, \mathrm{Ni}$, $\mathrm{Cu}, \mathrm{Co}, \mathrm{Pb}, \mathrm{Li}, \mathrm{Cr}, \mathrm{V}, \mathrm{As}$, and $\mathrm{Cd}$ were evaluated since they were of significance. All concentrations of these trace metals are below the [20] allowable limits Mn and Ba which had concentrations above permissible limits. However, the cumulative effects of long term consumption of these trace metals in the groundwater necessitated a health risk assessment.

Average concentrations of these trace metals were in the decreasing order as follows in $\mu \mathrm{g} / \mathrm{L}: \mathrm{Mn}$ (193.11), Fe (151.71), Ba (142.32), Sr (65.78), $\mathrm{Zn}$ (60.29), Ni (14.15), $\mathrm{Cu}$ (10.12), Co (7.47), Pb (2.31), Li (1.62), Cr (1.53), V (0.72), As (0.21) and $\mathrm{Cd}(0.16)$. The trace metal with the highest concentration is Mn with a maximum value of $687.20 \mu \mathrm{g} / \mathrm{L}$ detected at Bombe. 


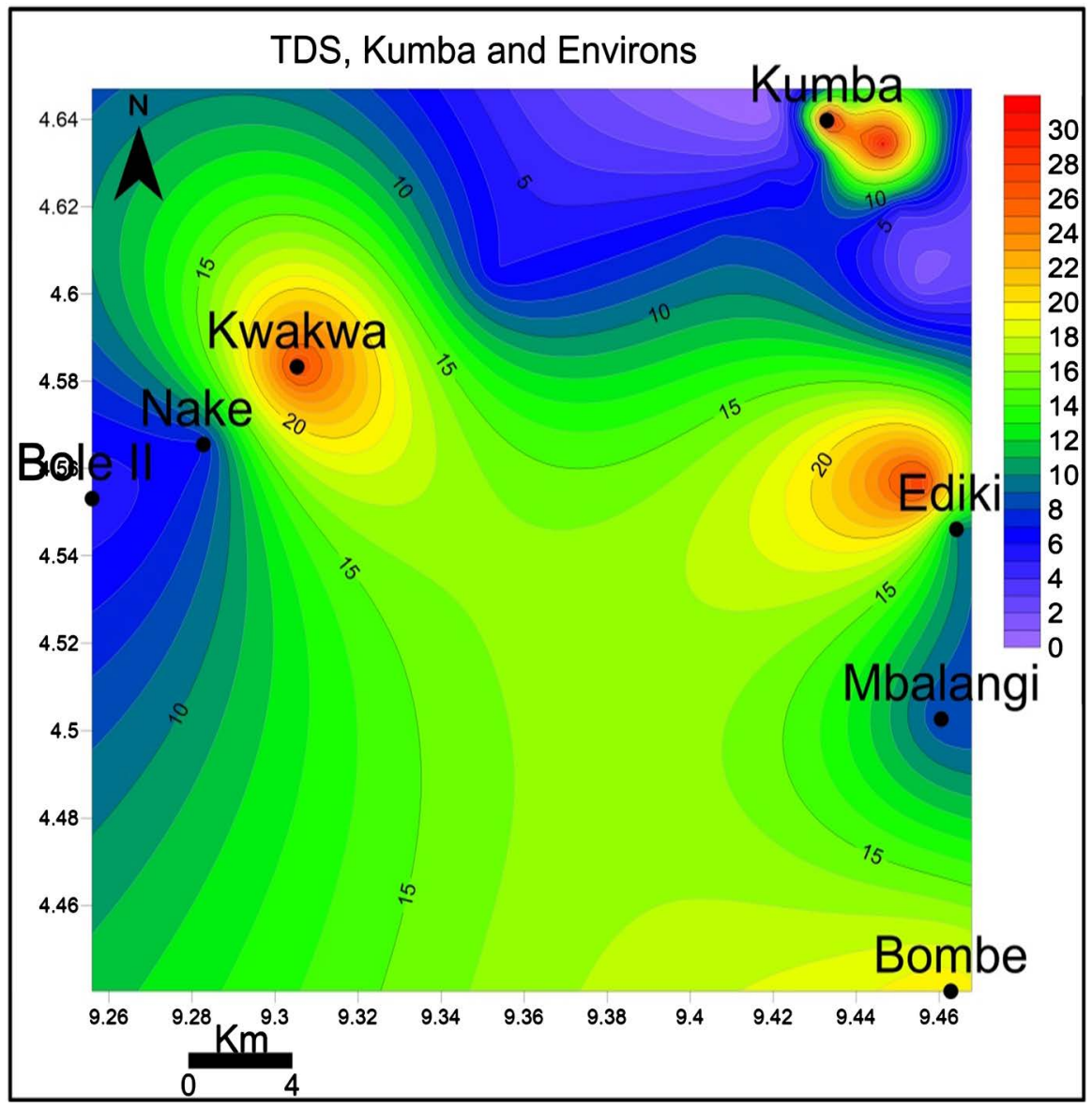

Figure 8. Spatial variation of total dissolved solids $\mathrm{mg} / \mathrm{L}$; TDS is maximum at Kumba, Kwakwa, Ediki and Bombe while minimum values are at Nake, Bole II, and Mbalangi.

\subsection{Pearson's Correlation Analysis PCA between Trace Metals and Physico-Chemical Parameters}

Correlation between trace metals in groundwater within the study area was carried out using Pearson's correlation analysis (PCA) as shown in Table 6 to establish the relationships that exist between the variables; trace metals and the physico-chemical parameters as in Table 2 . $\mathrm{r}$ values $>0.5$ or $<-0.5$ are significant, 0.72 strong (moderate) and 0.80 Very strong correlation.

In Table 6, a very strong positive correlation exists between the following; $\mathrm{Pb}$ and $\mathrm{Cu}(\mathrm{r}=0.82)$, $\mathrm{Cd}$ and $\mathrm{Zn}(\mathrm{r}=0.86)$, EC and As $(\mathrm{r}=0.98)$, TDS and As $(\mathrm{r}=$ $0.98), \mathrm{Ba}$ and $\mathrm{Sr}(\mathrm{r}=0.86)$. Moderately positive correlation exists between the following:

$\mathrm{Ni}$ and $\mathrm{Li}(\mathrm{r}=0.79)$, $\mathrm{Co}$ and $\mathrm{Mn}(\mathrm{r}=0.75), \mathrm{Ni}$ and $\mathrm{Co}(\mathrm{r}=0.72), \mathrm{Pb}$ and $\mathrm{Zn}(\mathrm{r}$ $=0.79), \mathrm{Pb}$ and $\mathrm{Cd}(\mathrm{r}=0.74)$. A moderately negative correlation exist between $\mathrm{V}$ and $\mathrm{Li}(\mathrm{r}=-0.04)$, $\mathrm{Sr}$ and $\mathrm{Li}(\mathrm{r}=-0.03), \mathrm{Cu}$ and $\mathrm{Co}(\mathrm{r}=-0.08)$. A high correlation coefficient (nearly 1 or -1 ) means a good relationship between two variables, and a correlation coefficient around zero means no relationship. Positive values indicate a positive relationship while negative values of $r$ indicate an inverse relationship [13]. 
Table 5. Trace metal concentration $(\mu \mathrm{g} / \mathrm{L})$ and basic statistics of groundwater in Mbonge-Kwakwa.

\begin{tabular}{|c|c|c|c|c|c|c|c|c|c|c|c|c|c|c|c|}
\hline SN & Location & $\mathrm{Li}$ & $\mathrm{V}$ & $\mathrm{Cr}$ & Mn & $\mathrm{Fe}$ & Co & $\mathrm{Ni}$ & $\mathrm{Cu}$ & $\mathrm{Zn}$ & As & $\mathrm{Sr}$ & $\mathrm{Cd}$ & $\mathrm{Ba}$ & $\mathrm{Pb}$ \\
\hline 1 & Bole II & 3.54 & 0.40 & 1.61 & 167.98 & 401.38 & 15.28 & 28.40 & 8.60 & 92.14 & 0.09 & 43.36 & 0.32 & 172.00 & 2.25 \\
\hline 2 & Nake & 3.02 & 1.25 & 2.19 & 93.25 & 346.91 & 2.45 & 13.81 & 23.64 & 168.50 & 0.18 & 69.35 & 0.34 & 195.67 & 6.37 \\
\hline 3 & Kwakwa & 1.84 & 0.44 & 0.48 & 374.93 & 85.13 & 12.67 & 16.67 & 6.97 & 106.41 & 0.51 & 358.42 & 0.25 & 1640.18 & 1.33 \\
\hline 4 & Kumba & 1.16 & 0.41 & 0.79 & 178.29 & 105.45 & 6.64 & 15.62 & 20.20 & 68.39 & 0.09 & 65.06 & 0.18 & 200.40 & 2.03 \\
\hline 5 & Kumba & 0.24 & 1.43 & 1.54 & 15.37 & 88.29 & 1.25 & 4.49 & 7.12 & 56.05 & 0.05 & 102.54 & 0.13 & 15.05 & 1.55 \\
\hline 6 & Kumba & 1.58 & 0.18 & 0.32 & 254.78 & 60.32 & 9.15 & 21.51 & 5.05 & 31.98 & 0.09 & 30.21 & 0.11 & 141.90 & 1.12 \\
\hline 7 & Kumba & 0.76 & 0.17 & 0.22 & 86.25 & 52.29 & 4.36 & 7.35 & 3.10 & 15.11 & 0.10 & 12.49 & 0.05 & 59.03 & 0.87 \\
\hline 8 & Kumba & 1.59 & 0.42 & 0.95 & 158.97 & 109.69 & 5.69 & 19.41 & 6.91 & 55.28 & 0.14 & 12.57 & 0.15 & 29.65 & 1.95 \\
\hline 9 & Kumba & 1.60 & 1.00 & 10.25 & 268.04 & 176.20 & 5.80 & 16.66 & 13.32 & 96.63 & 0.68 & 110.15 & 0.28 & 76.08 & 3.82 \\
\hline 10 & Kumba & 2.79 & 0.47 & 2.60 & 116.30 & 98.38 & 12.43 & 39.46 & 7.90 & 35.44 & 0.13 & 39.95 & 0.15 & 32.94 & 1.87 \\
\hline 11 & Kumba & 1.74 & 0.63 & 0.98 & 520.70 & 263.54 & 9.55 & 7.42 & 8.21 & 53.08 & 0.05 & 8.07 & 0.12 & 9.03 & 2.17 \\
\hline 12 & Kumba & 2.56 & 0.72 & 1.00 & 610.96 & 146.44 & 28.89 & 27.18 & 10.35 & 70.62 & 0.29 & 70.44 & 0.20 & 77.27 & 2.36 \\
\hline 13 & Kumba & 0.92 & 1.63 & 1.05 & 37.28 & 369.14 & 1.87 & 5.19 & 18.62 & 67.31 & 0.10 & 9.98 & 0.14 & 4.26 & 3.13 \\
\hline 14 & Kumba & 0.76 & 1.43 & 0.66 & 36.31 & 116.20 & 3.93 & 4.34 & 8.56 & 74.44 & 0.54 & 73.28 & 0.13 & 14.13 & 3.19 \\
\hline 15 & Kumba & 1.32 & 0.89 & 0.98 & 134.78 & 173.51 & 2.91 & 7.52 & 18.57 & 80.32 & 0.20 & 30.46 & 0.28 & 21.42 & 5.15 \\
\hline 16 & Kumba & 0.24 & 0.51 & 1.17 & 46.93 & 77.62 & 3.75 & 3.17 & 4.98 & 3.20 & 0.55 & 183.77 & 0.03 & 97.17 & 1.10 \\
\hline 17 & Kumba & 0.62 & 0.45 & 0.97 & 51.87 & 106.89 & 2.80 & 4.53 & 5.86 & 22.07 & 0.07 & 18.00 & 0.04 & 10.70 & 0.94 \\
\hline 18 & Barombi N & 0.47 & 0.24 & 0.52 & 25.77 & 51.13 & 1.66 & 2.28 & 3.62 & 9.73 & 0.03 & 5.00 & 0.04 & 4.50 & 1.00 \\
\hline 19 & Ediki & 2.84 & 1.16 & 2.22 & 152.86 & 151.18 & 10.59 & 28.61 & 12.35 & 56.83 & 0.17 & 55.31 & 0.14 & 106.42 & 2.37 \\
\hline 20 & Mbalangi & 2.00 & 0.68 & 1.00 & 36.46 & 102.45 & 1.64 & 4.77 & 7.94 & 39.38 & 0.12 & 23.96 & 0.05 & 16.77 & 1.04 \\
\hline 21 & Bombe & 2.37 & 0.56 & 0.54 & 687.20 & 103.70 & 13.46 & 18.72 & 10.68 & 63.27 & 0.33 & 59.01 & 0.29 & 64.23 & 2.98 \\
\hline Min & & 0.24 & 0.17 & 0.22 & 15.37 & 51.13 & 1.25 & 2.28 & 3.10 & 3.20 & 0.03 & 5.00 & 0.03 & 4.26 & 0.87 \\
\hline $\operatorname{Max}$ & & 3.54 & 1.63 & 10.25 & 687.20 & 401.38 & 28.89 & 39.46 & 23.64 & 168.50 & 0.68 & 358.42 & 0.34 & 1640.18 & 6.37 \\
\hline Mean & & 1.62 & 0.72 & 1.53 & 193.11 & 151.71 & 7.47 & 14.15 & 10.12 & 60.29 & 0.21 & 65.78 & 0.16 & 142.32 & 2.31 \\
\hline
\end{tabular}

\subsection{Hierarchical Cluster Analysis HCA}

The R-mode Cluster Analysis; hierarchical cluster analysis HCA performed on the groundwater of Kumba and environs area shows two clusters based on spatial similarities and dissimilarities. The trace metals fall in two clusters: Cluster one; (01) element $\mathrm{Ba}$; soluble. Cluster two (13) non soluble elements divided into three classes; class one (06) $\mathrm{As}, \mathrm{Cd}, \mathrm{V}, \mathrm{Li}, \mathrm{Pb}$, and $\mathrm{Cr}$; less enriched. Class two (03) $\mathrm{Co}, \mathrm{Cu}, \mathrm{Ni}$ and $\mathrm{Zn}$; enriched; Class two (04) Zn, Sr, Fe and Mn; more enriched (Figure 9).

\subsection{Health Risk Assessment}

Human health risk assessment was done to estimate the intensity, frequency, and duration of human exposures to an environmental contaminant. Exposure assessment was carried out by measuring the average daily dose ADD of the trace 
Table 6. Correlation matrix of $\mathrm{r}$ values for trace metals and physico-chemical parameters in study area.

\begin{tabular}{|c|c|c|c|c|c|c|c|c|c|c|c|c|c|c|c|c|c|c|}
\hline & $\mathrm{Li}$ & $\mathrm{V}$ & $\mathrm{Cr}$ & $\mathrm{Mn}$ & $\mathrm{Fe}$ & Co & $\mathrm{Ni}$ & $\mathrm{Cu}$ & $\mathrm{Zn}$ & As & $\mathrm{Sr}$ & $\mathrm{Cd}$ & $\mathrm{Ba}$ & $\mathrm{Pb}$ & Temp & $\mathrm{PH}$ & EC & TDS \\
\hline $\mathrm{Li}$ & 1 & & & & & & & & & & & & & & & & & \\
\hline $\mathrm{V}$ & -0.04 & 1 & & & & & & & & & & & & & & & & \\
\hline $\mathrm{Cr}$ & 0.16 & 0.26 & 1 & & & & & & & & & & & & & & & \\
\hline Mn & 0.42 & -0.22 & 0.01 & 1 & & & & & & & & & & & & & & \\
\hline $\mathrm{Fe}$ & 0.48 & 0.44 & 0.17 & 0.02 & 1 & & & & & & & & & & & & & \\
\hline Co & 0.61 & -0.25 & -0.03 & 0.75 & 0.07 & 1 & & & & & & & & & & & & \\
\hline $\mathrm{Ni}$ & 0.79 & -0.21 & 0.20 & 0.38 & 0.11 & 0.72 & 1 & & & & & & & & & & & \\
\hline $\mathrm{Cu}$ & 0.30 & 0.54 & 0.23 & 0.01 & 0.58 & -0.08 & 0.1 & 1 & & & & & & & & & & \\
\hline $\mathrm{Zn}$ & 0.53 & 0.46 & 0.30 & 0.20 & 0.61 & 0.15 & 0.2 & 0.71 & 1 & & & & & & & & & \\
\hline As & -0.05 & 0.19 & 0.49 & 0.21 & -0.14 & 0.13 & 0.0 & 0.02 & 0.26 & 1 & & & & & & & & \\
\hline $\mathrm{Sr}$ & -0.03 & 0.01 & 0.10 & 0.17 & -0.19 & 0.17 & 0.0 & -0.07 & 0.29 & 0.65 & 1 & & & & & & & \\
\hline $\mathrm{Cd}$ & 0.64 & 0.23 & 0.34 & 0.42 & 0.54 & 0.35 & 0.4 & 0.62 & 0.86 & 0.27 & 0.24 & 1 & & & & & & \\
\hline $\mathrm{Ba}$ & 0.14 & -0.18 & -0.10 & 0.23 & -0.09 & 0.23 & 0.1 & -0.05 & 0.36 & 0.35 & 0.86 & 0.29 & 1 & & & & & \\
\hline $\mathrm{Pb}$ & 0.35 & 0.57 & 0.34 & 0.08 & 0.58 & -0.07 & 0.1 & 0.82 & 0.79 & 0.22 & -0.07 & 0.74 & -0.1 & 1 & & & & \\
\hline Temp & 0.41 & 0.00 & 0.04 & -0.12 & 0.17 & -0.08 & 0.1 & 0.26 & 0.43 & 0.07 & 0.25 & 0.35 & 0.4 & 0.21 & 1 & & & \\
\hline $\mathrm{PH}$ & -0.13 & 0.46 & 0.37 & -0.29 & 0.16 & -0.26 & -0.1 & 0.27 & 0.24 & 0.19 & 0.32 & 0.10 & 0.1 & 0.23 & -0.16 & 1 & & \\
\hline EC & -0.11 & 0.15 & 0.42 & 0.21 & -0.25 & 0.13 & 0.0 & -0.08 & 0.18 & 0.98 & 0.68 & 0.22 & 0.4 & 0.12 & 0.05 & 0.19 & 1 & \\
\hline TDS & -0.11 & 0.15 & 0.42 & 0.21 & -0.25 & 0.13 & 0.0 & -0.08 & 0.18 & 0.98 & 0.68 & 0.22 & 0.4 & 0.12 & 0.05 & 0.19 & 1 & 1 \\
\hline
\end{tabular}

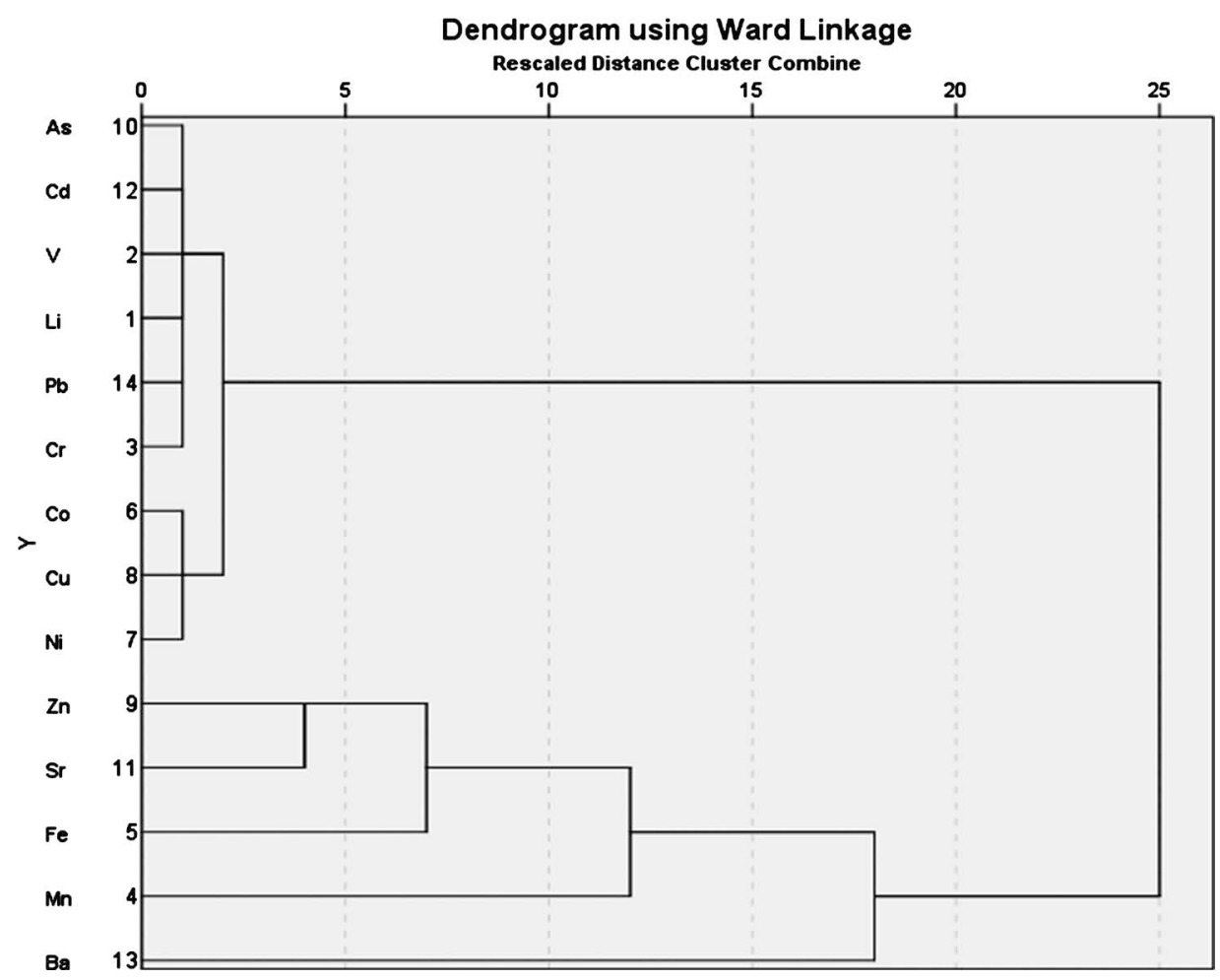

Figure 9. Dendrogram of trace metals in groundwater of the Akwa-Mundemba area made up of two clusters: cluster 1 (01) element $\mathrm{Ba}$; soluble. Cluster two (13) non soluble elements divided into three classes; class one (06) $\mathrm{As}, \mathrm{Cd}, \mathrm{V}, \mathrm{Li}, \mathrm{Pb}, \mathrm{Cr}$; less enriched. Class two (03) Co, Cu, Ni and Zn; enriched; Class two (04) Zn, Sr, Fe and Mn; more enriched. 
metals selected in Table 7. Carcinogenic and non carcinogenic risk were calculated from the ADD.

\subsection{Average Daily Dose}

ADD values ranged as follows; ( $\mathrm{Li}) 8 \times 10^{-6}$ to $1 \times 10^{-4}$, (V) $5.5 \times 10^{-6}$ to $5.1 \times$ $10^{-5}$, (Cr) $7 \times 10^{-6}$ to $3.2 \times 10^{-4}$, (Mn) $5 \times 10^{-4}$ to 0.022 , (Fe) $2 \times 10^{-3}$ to 0.013 , (Co) $4 \times 10^{-5}$ to $9 \times 10^{-4}$, (Ni) $7 \times 10^{-5}$ to $1.2 \times 10^{-3}$, (Cu) $1 \times 10^{-4}$ to $7 \times 10^{-4}$, (Zn) $1.4 \times 10^{-4}$ to $5 \times 10^{-3}$, (As) $1 \times 10^{-6}$ to $2 \times 10^{-5}$, (Sr) $2 \times 10^{-4}$ to 0.011 , (Cd) $1 \times 10^{-6}$ to $1 \times 10^{-5}$, (Ba) $1 \times 10^{-4}$ to 0.052 , (Pb) $3 \times 10^{-5}$ to $2 \times 10^{-4}$ as in Figure 10.

\subsection{Hazard Qotient}

HQ values ranged as follow; (V) $2.7 \times 10^{-3}$ to $2.5 \times 10^{-2}$, (Cu) $2.4 \times 10^{-3}$ to $1.8 \times$ $10^{-2},(\mathrm{~Pb}) 7.8 \times 10^{-3}$ to $5.7 \times 10^{-2}$, ( $\left.\mathrm{Zn}\right) 3.3 \times 10^{-5}$ to $1.7 \times 10^{-2}$, (Fe) $2.2 \times 10^{-3}$ to $1.8 \times 10^{-2},(\mathrm{Mn}) 7.6 \times 10^{-2}$ to 1.59 as in Figure 11 .

\subsection{Carcinogenic Risk}

CR for the carcinogenic elements; $\mathrm{Cr}, \mathrm{Cd}, \mathrm{Ni}$ and As are; (As) $2.2 \times 10^{-4}$ to $4.4 \times$ $10^{-4}$, (Cd) $8.5 \times 10^{-6}$ to $8.8 \times 10^{-5}$, (Cr) $3.9 \times 10^{-4}$ to $1.8 \times 10^{-2}$, (Ni) $8.6 \times 10^{-5}$ to $1.4 \times 10^{-3}$ as in Figure 12 .

Table 7. Parameters used for estimating exposure assessment [9].

\begin{tabular}{cccc}
\hline Factor/parameter & Symbol & Units & Residential \\
\hline Exposure duration & ED & Years & 30 \\
Exposure frequency & EF & Days in year & 350 \\
Average time & AT & Years & 76.5 \\
Body weight & BW & Kg & 70 \\
Ingestion rate & IR & L/day & 2.2 \\
Contaminant concentration & C & ug/L & Table 5
\end{tabular}

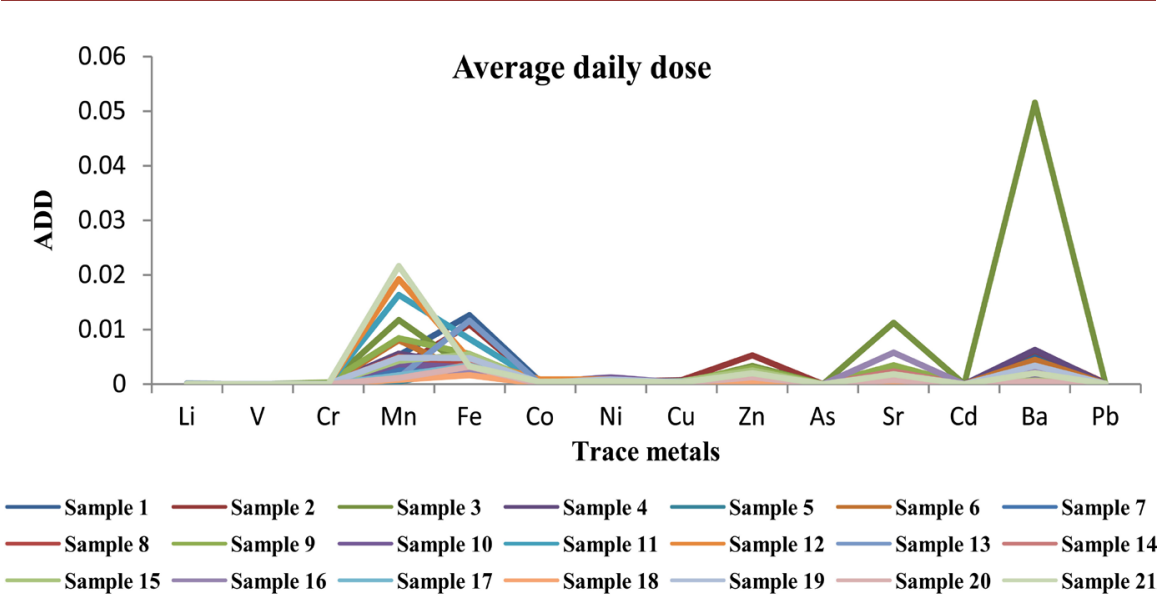

Figure 10. Average Daily Dose (ADD) of trace metals through water intake. All values are below toxic level in Kumba and envurons. 


\subsection{Hazard Index}

$\mathrm{HI}$ is the cumulative sum of HQ. The values ranged between 0.07 and 1.59 for each of contaminant indicating no toxicity as in Figure 13.

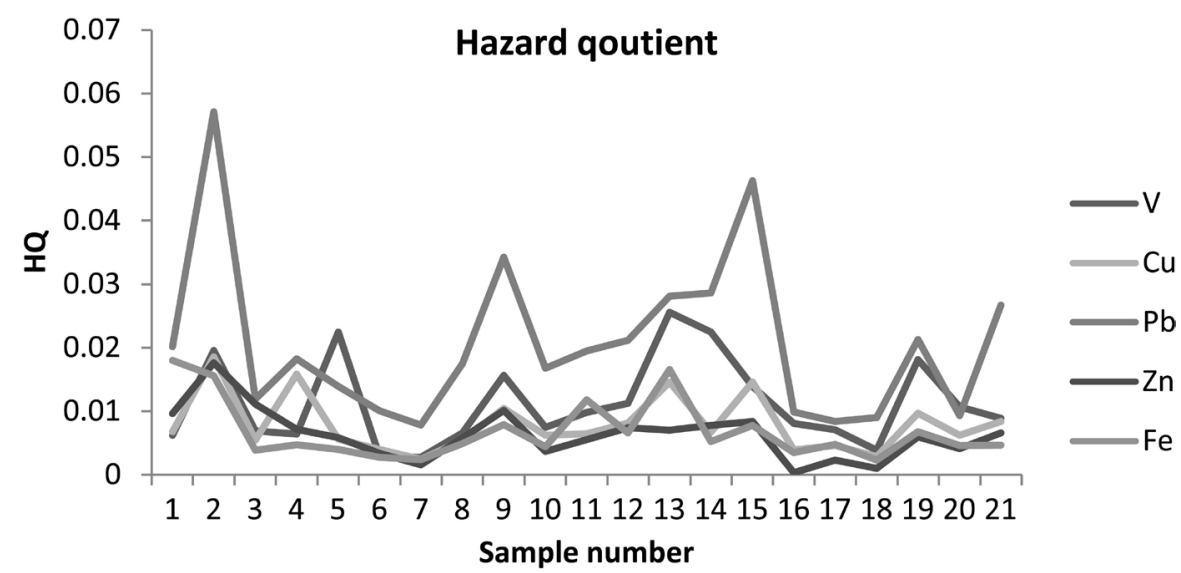

Figure 11. Hazard quotient (HQ) of trace metals through water intake. The value of Manganese in sample12 is above permissible levels in Kumba and environs.

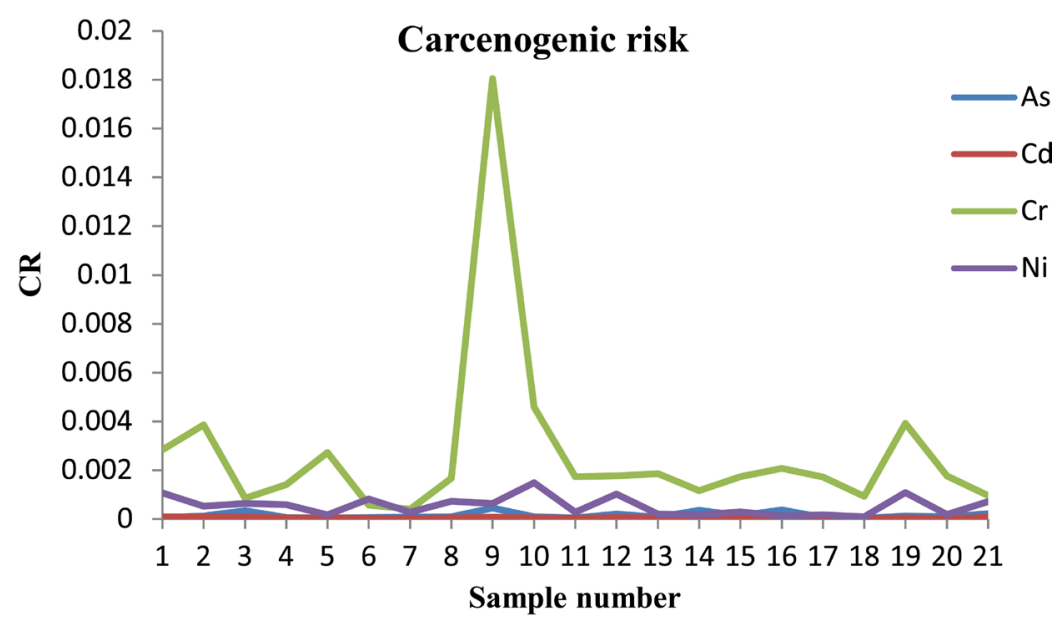

Figure 12. Carcinogenic risk (CR) of each contaminant.. All values are below toxic levels.

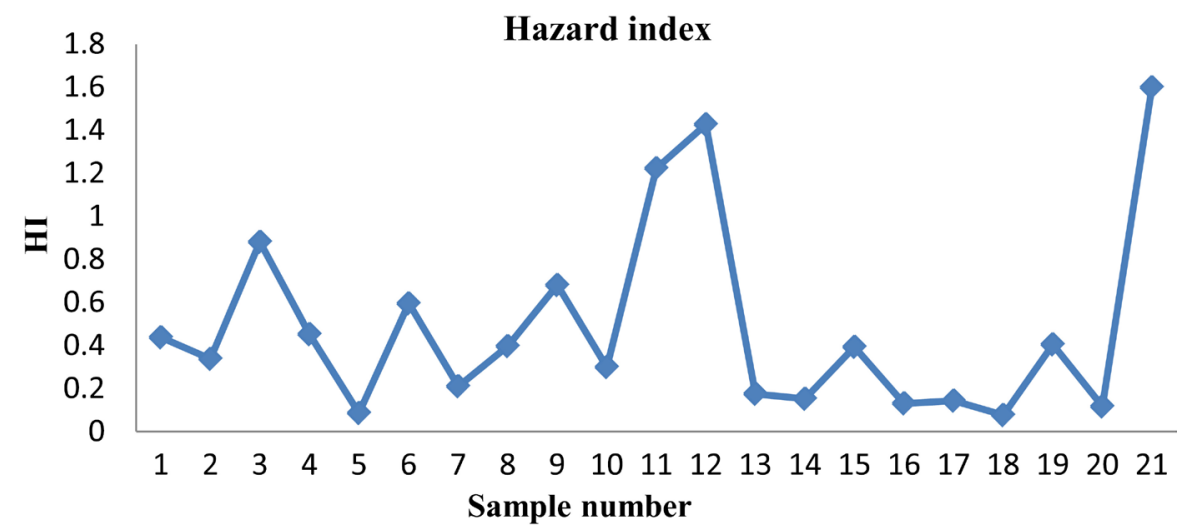

Figure 13. Non carcinogenic toxic risk index or hazard index (HI) of trace metals through water intake. The values in sample 11 (Kwakwa) is relatively high. All values are below toxic levels. 
All the groundwater hazard risk indices; ADD, CR, HQ and HI were less than 1 but for sample 20 which had HI value greater than 1 , thus the water is of significant health risk as shown in Table 8.

\subsection{Pollution Evaluation Indices}

\section{Degree of contamination (DC)}

The degree of contamination (DC) is used as reference of estimating the extent of metal pollution. The DC values in the groundwater ranged from -13.53 to 12.1 According to classification [15], 95.2\% of the samples have degree of contamination factor $<10$ which is indicative of low contamination whereas $4.8 \%$ of the samples have degree of contamination factor between 10 - 20 thus indicating moderate contamination.

\section{Enrichment factor}

Iron $(\mathrm{Fe})$ was chosen as a stationary reference element to perform this calculation [22]. EF values $<2$ indicate that the metal is entirely from crustal materials or natural processes; whereas EF values $>2$ reveal that the sources are more likely to be anthropogenic [23]. The enrichment factors of trace metals in Kumba and environs were as shown in Figure 14, Figure 15 and Table 9. The sequence of $\mathrm{EF}$ in the sediments was $\mathrm{Ba}>\mathrm{Co}>\mathrm{Mn}>\mathrm{Ni}>\mathrm{Pb}>\mathrm{Cd}>\mathrm{Cr}>\mathrm{As}>$ $\mathrm{Sr}>\mathrm{Zn}>\mathrm{Li}>\mathrm{Cu}>\mathrm{V}$. EF values in the study area are between 1.15 to 874.13 which is indicative of significant enrichment and that the source of these metals is from natural and anthropogenic processes. Barium and Cobalt are the most enriched elements in the study area; this could be attributed to agricultural wastes.

\subsection{Ecological Risk Assessment}

\section{Ecological Risk Factor (Er) and Ecological Risk Index (RI)}

$\mathrm{Er}$ and RI of the heavy metals in the investigated area are given in Table 9 and Figure 16 and Figure 17. All analyzed trace metals showed low potential ecological risk, it varied from -29.68 to $9.45(\mathrm{Er}<40)$. RI of the studied trace metals ranged from -61.06 to -43.03 . All the samples show low ecological risk index, this indicates low polluted according to [17].

Table 8. Summary Classification of health risk assessment carcinogenic and non-carcinogenic risk in Akwa-Mundemba.

\begin{tabular}{cccccc}
\hline INDEX & Range & Classification & Samples & $(\%)$ & Reference \\
\hline CR & $>10^{-6}-10^{-4}<$ & Generally satisfactory & 21 & 100 & \\
& $>10^{-4}$ & Intolerable & - & - & {$[15]$} \\
HQ & $<1$ & Acceptable level (no concern) & 18 & 85.7 & \\
& $>1$ & No carcinogenic adverse effects & 3 & 24.3 & {$[21]$} \\
HI & $<1$ & Safe & 18 & 85.7 & \\
& $>1$ & Unsafe & 3 & 24.3 & {$[21]$} \\
\hline
\end{tabular}




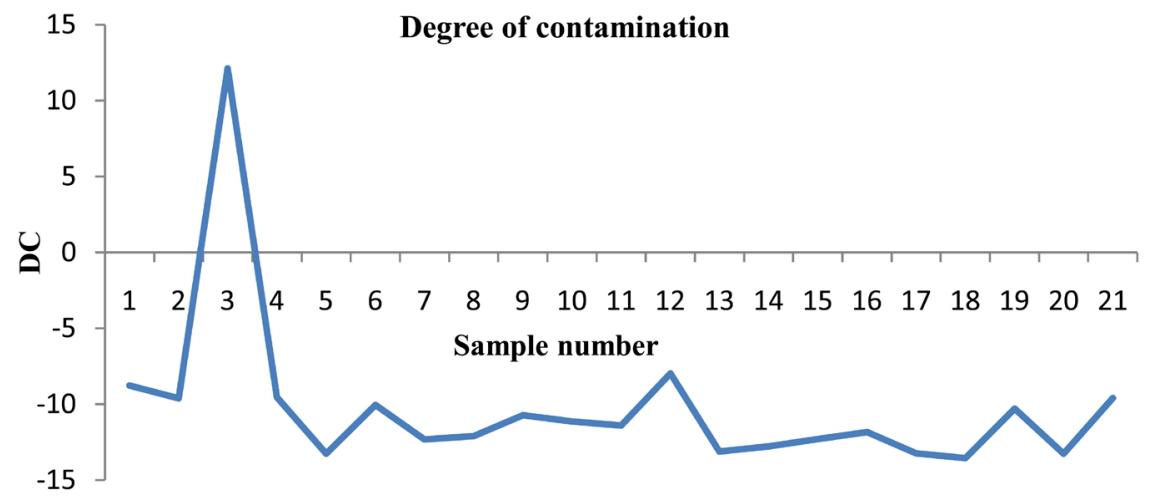

Figure 14. The degree of contamination for trace metals of groundwater in kumba and environs with sample 3 indicating moderate contamination.

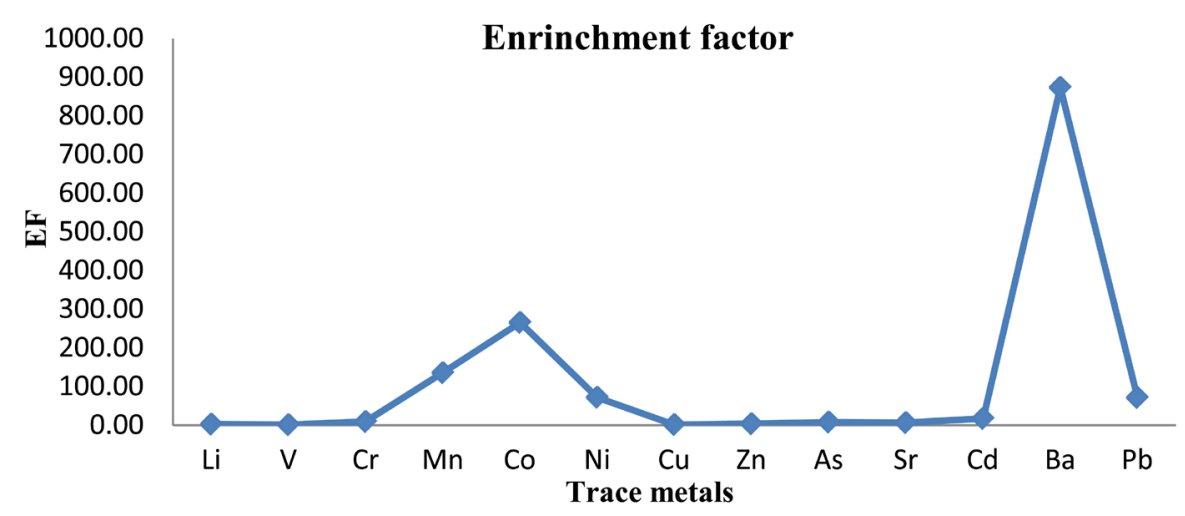

Figure 15. The enrichment factor for trace metal of groundwater in kumba and environs. Barium and Cobalt, are being enriched.

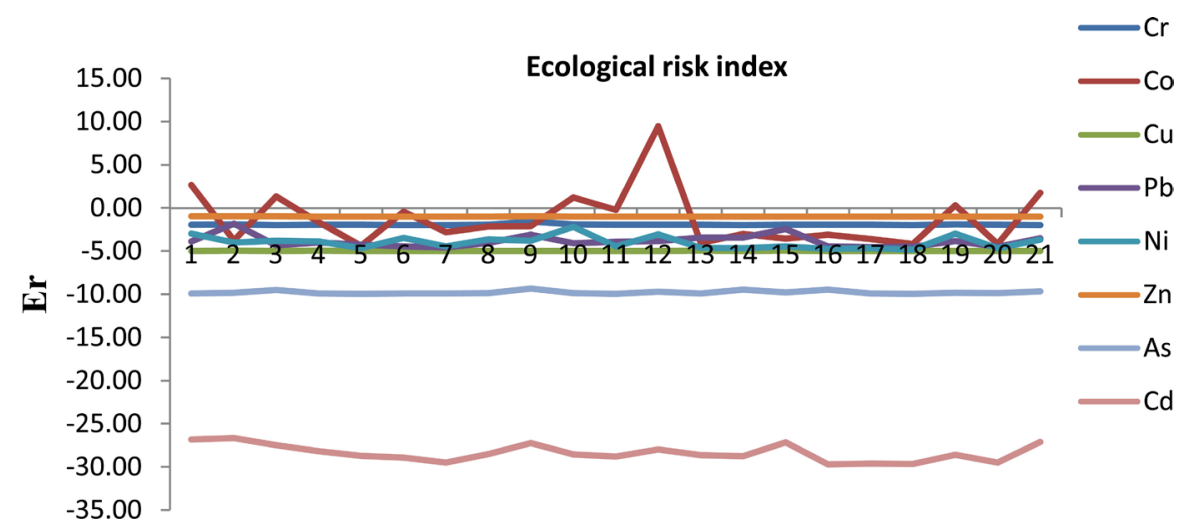

Figure 16. The Ecological risk factor Er for trace metal of groundwater in Kumba and environs.

\section{Pollution Load Index (PLI)}

This index is a quick tool in order to compare the pollution status of different places [24]. The values of Pollution Load Index are $<1$ which is indicative that there is no pollution. These results attributed principally to natural sources.

\section{Geo-Accumulation Index Igeo}

The geo-accumulation index Igeo is a quantitative measure of the degree of pollution in groundwater [25] as shown in Table 9 presents the indices for the 


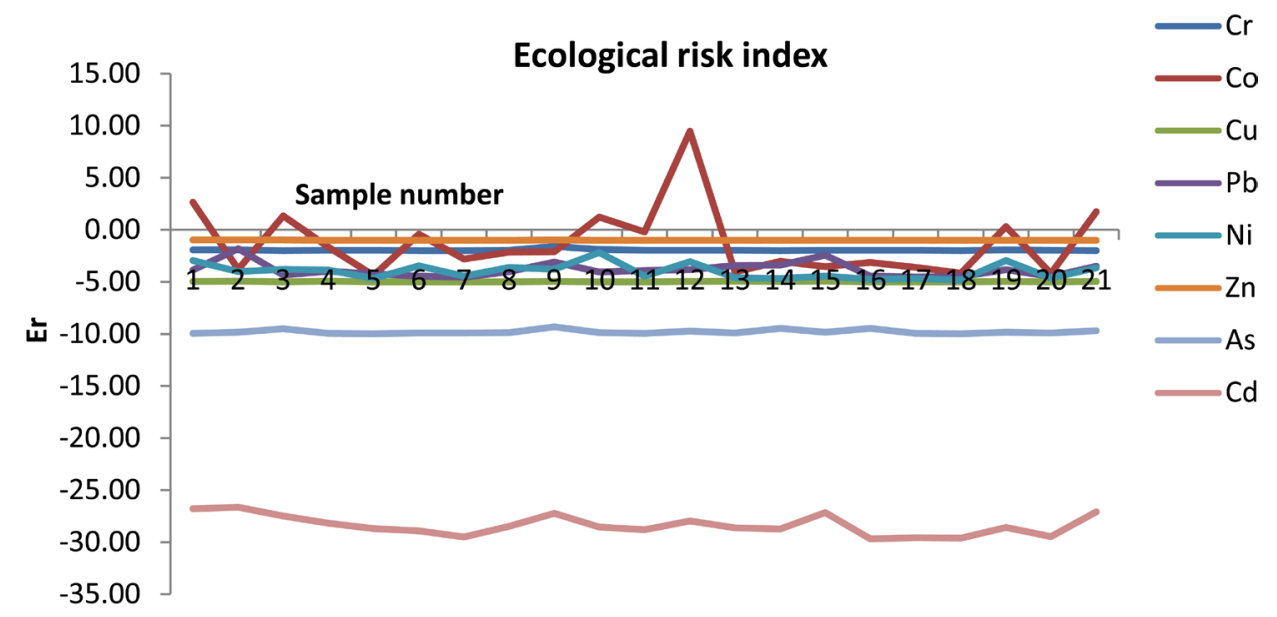

Figure 17. The Ecological risk index for trace metalof groundwater in Kumba and environs.

Table 9. The Geo-accumulation index (Igeo) of Kumba and environs groundwater.

\begin{tabular}{|c|c|c|c|c|c|c|c|c|c|c|c|c|c|c|}
\hline SN & $\mathrm{Li}$ & $\mathrm{V}$ & $\mathrm{Cr}$ & $\mathrm{Mn}$ & $\mathrm{Fe}$ & Co & $\mathrm{Ni}$ & $\mathrm{Cu}$ & $\mathrm{Zn}$ & As & $\mathrm{Sr}$ & Cd & $\mathrm{Ba}$ & $\mathrm{Pb}$ \\
\hline 1 & 0.14 & 0.016 & 0.016 & 16.8 & 160.6 & 0.031 & 3.975 & 3.44 & 92.14 & $2 \mathrm{E}-04$ & 34.7 & $2 \mathrm{E}-04$ & 2.408 & 0.031 \\
\hline 2 & 0.12 & 0.05 & 0.022 & 9.325 & 138.8 & 0.005 & 1.934 & 9.457 & 168.5 & $4 \mathrm{E}-04$ & 55.5 & $2 \mathrm{E}-04$ & 2.739 & 0.089 \\
\hline 3 & 0.07 & 0.018 & 0.005 & 37.49 & 34.05 & 0.025 & 2.333 & 2.787 & 106.4 & 0.001 & 287 & $2 \mathrm{E}-04$ & 22.96 & 0.019 \\
\hline 4 & 0.05 & 0.016 & 0.008 & 17.83 & 42.18 & 0.013 & 2.187 & 8.082 & 68.39 & $2 \mathrm{E}-04$ & 52.1 & $1 \mathrm{E}-04$ & 2.806 & 0.028 \\
\hline 5 & 0.01 & 0.057 & 0.015 & 1.537 & 35.31 & 0.002 & 0.629 & 2.849 & 56.05 & $9 \mathrm{E}-05$ & 82 & $8 \mathrm{E}-05$ & 0.211 & 0.022 \\
\hline 6 & 0.06 & 0.007 & 0.003 & 25.48 & 24.13 & 0.018 & 3.011 & 2.019 & 31.98 & $2 \mathrm{E}-04$ & 24.2 & $7 E-05$ & 1.987 & 0.016 \\
\hline 7 & 0.03 & 0.007 & 0.002 & 8.625 & 20.92 & 0.009 & 1.028 & 1.238 & 15.11 & $2 \mathrm{E}-04$ & 9.99 & $3 \mathrm{E}-05$ & 0.826 & 0.012 \\
\hline 8 & 0.06 & 0.017 & 0.009 & 15.9 & 43.88 & 0.011 & 2.718 & 2.764 & 55.28 & $3 \mathrm{E}-04$ & 10.1 & $9 \mathrm{E}-05$ & 0.415 & 0.027 \\
\hline 9 & 0.06 & 0.04 & 0.102 & 26.8 & 70.48 & 0.012 & 2.333 & 5.326 & 96.63 & 0.001 & 88.1 & $2 \mathrm{E}-04$ & 1.065 & 0.053 \\
\hline 10 & 0.11 & 0.019 & 0.026 & 11.63 & 39.35 & 0.025 & 5.524 & 3.158 & 35.44 & $3 \mathrm{E}-04$ & 32 & $9 \mathrm{E}-05$ & 0.461 & 0.026 \\
\hline 11 & 0.07 & 0.025 & 0.01 & 52.07 & 105.4 & 0.019 & 1.039 & 3.284 & 53.08 & $1 \mathrm{E}-04$ & 6.45 & $7 \mathrm{E}-05$ & 0.126 & 0.03 \\
\hline 12 & 0.1 & 0.029 & 0.01 & 61.1 & 58.58 & 0.058 & 3.805 & 4.139 & 70.62 & $6 \mathrm{E}-04$ & 56.4 & $1 \mathrm{E}-04$ & 1.082 & 0.033 \\
\hline 13 & 0.04 & 0.065 & 0.01 & 3.728 & 147.7 & 0.004 & 0.726 & 7.448 & 67.31 & $2 \mathrm{E}-04$ & 7.98 & $8 \mathrm{E}-05$ & 0.06 & 0.044 \\
\hline 14 & 0.03 & 0.057 & 0.007 & 3.631 & 46.48 & 0.008 & 0.608 & 3.423 & 74.44 & 0.001 & 58.6 & $8 \mathrm{E}-05$ & 0.198 & 0.045 \\
\hline 15 & 0.05 & 0.035 & 0.01 & 13.48 & 69.41 & 0.006 & 1.053 & 7.428 & 80.32 & $4 \mathrm{E}-04$ & 24.4 & $2 \mathrm{E}-04$ & 0.3 & 0.072 \\
\hline 16 & 0.01 & 0.021 & 0.012 & 4.693 & 31.05 & 0.008 & 0.444 & 1.99 & 3.199 & 0.001 & 147 & $2 \mathrm{E}-05$ & 1.36 & 0.015 \\
\hline 17 & 0.02 & 0.018 & 0.01 & 5.187 & 42.76 & 0.006 & 0.635 & 2.342 & 22.07 & $1 \mathrm{E}-04$ & 14.4 & $3 \mathrm{E}-05$ & 0.15 & 0.013 \\
\hline 18 & 0.02 & 0.01 & 0.005 & 2.577 & 20.45 & 0.003 & 0.32 & 1.448 & 9.729 & $7 \mathrm{E}-05$ & 4 & $2 \mathrm{E}-05$ & 0.063 & 0.014 \\
\hline 19 & 0.11 & 0.046 & 0.022 & 15.29 & 60.47 & 0.021 & 4.005 & 4.941 & 56.83 & $3 \mathrm{E}-04$ & 44.2 & $9 \mathrm{E}-05$ & 1.49 & 0.033 \\
\hline 20 & 0.08 & 0.027 & 0.01 & 3.646 & 40.98 & 0.003 & 0.668 & 3.177 & 39.38 & $2 \mathrm{E}-04$ & 19.2 & $3 \mathrm{E}-05$ & 0.235 & 0.015 \\
\hline 21 & 0.09 & 0.023 & 0.005 & 68.72 & 41.48 & 0.027 & 2.621 & 4.273 & 63.27 & $7 \mathrm{E}-04$ & 47.2 & $2 \mathrm{E}-04$ & 0.899 & 0.042 \\
\hline Min & 0.01 & 0.007 & 0.002 & 1.537 & 20.45 & 0.002 & 0.32 & 1.238 & 3.199 & $7 E-05$ & 4 & $2 \mathrm{E}-05$ & 0.06 & 0.012 \\
\hline $\operatorname{Max}$ & 0.14 & 0.065 & 0.102 & 68.72 & 160.6 & 0.058 & 5.524 & 9.457 & 168.5 & 0.001 & 287 & $2 \mathrm{E}-04$ & 22.96 & 0.089 \\
\hline Mean & 0.06 & 0.029 & 0.015 & 19.31 & 60.68 & 0.015 & 1.981 & 4.048 & 60.29 & $4 \mathrm{E}-04$ & 52.6 & $1 \mathrm{E}-04$ & 1.993 & 0.032 \\
\hline
\end{tabular}


quantification of trace metal accumulation in the Akwa-Mundemba. The values range as in Table 4. Groundwater is Unpolluted to moderately polluted by $\mathrm{Pb}$, $\mathrm{V}, \mathrm{Cr}, \mathrm{Co}, \mathrm{As}, \mathrm{Cd}, \mathrm{Pb}$; while it is Extremely polluted by $\mathrm{Mn}, \mathrm{Fe}, \mathrm{Ni}, \mathrm{Cu}, \mathrm{Sr}, \mathrm{Zn}$, $\mathrm{Ba}$ (Figure 18).

The results of pollution evaluation indices are presented in Table 10 .

\section{Conclusions}

The groundwater in Kumba and environs presents no pollution risks or hazards.

The degree of contamination and contamination factors such as the ER, EF, PLI and Igeo had low values of trace metals indicating that, the groundwater is unpolluted with Barium being the most enriched metal. Thus, from health risk indices and pollution evaluation indices of trace metals, the groundwater in Kumba and environs area is safe for drinking.

The enrichment factors show that the sources of the trace metals are from geogenic and anthropogenic processes.

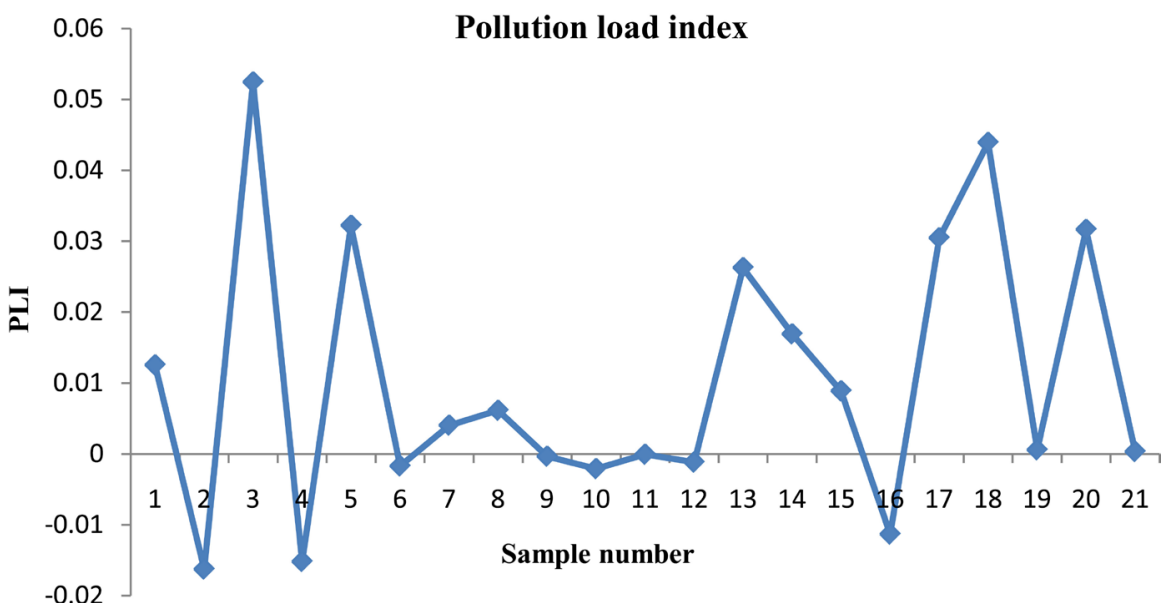

Figure 18. The Pollution load index for trace metalof groundwater in Kumba and environs.

Table 10. Summary Classification of Kumba and environs groundwater based on pollution evaluation indices.

\begin{tabular}{ccccc}
\hline INDEX & Range & Classification & SN & $\%$ \\
\hline DC & $<10$ & low degree of contamination factor & 20 & 95.2 \\
& $10-20$ & moderate degree of contamination & 1 & 4.8 \\
EF & $2-5$ & Moderate enrichment & 2 & 9.52 \\
& $5-20$ & Significant enrichment & 10 & 47.62 \\
& $20-40$ & Very high enrichment & 9 & 42.86 \\
Er & $<40$ & Low potential risk & 21 & 100 \\
RI & $<150$ & Low ecological risk & 21 & 100 \\
PLI & $<1$ & No pollution & 21 & 100 \\
Igeo & $0-1$ & Unpolluted to moderately polluted by & $\mathrm{Pb}, \mathrm{V}, \mathrm{Cr}, \mathrm{Co}, \mathrm{As}, \mathrm{Cd}, \mathrm{Pb}$ \\
& $>5$ & Extremely polluted by & $\mathrm{Mn}, \mathrm{Fe}, \mathrm{Ni}, \mathrm{Cu}, \mathrm{Sr}, \mathrm{Zn}, \mathrm{Ba}$ \\
\hline
\end{tabular}


The severity of metal toxicity is governed by several factors, such as dose, nutrition, age, and even life style. Therefore, these low trends might not guarantee the complete absence of human health risks. Generally, from risk assessment on trace metals using risk indices in the analyzed groundwater samples might not cause any health risk. However, due to an increasing level of environmental pollution that might be imposed by increasing human activity in this area, groundwater sources might become a potential sink of contaminants; this is significant reason that makes constant monitoring, implementation and treatment of groundwater for drinking purposes necessary.

The trace metal concentrations in the study are within WHO permissible limits except that of Barium and Manganese which are above permissible limits.

\section{Conflicts of Interest}

The authors declare no conflicts of interest regarding the publication of this paper.

\section{References}

[1] Mehri, A. and Marjan, R.F. (2013) Trace Metals in Human Nutrition: A Review. International Journal of Medical Investigation, 2, 115-128.

[2] Akoachere, R.A., Etone, E.N., Mbua, R.L., Ngassam, M.P., Longonje, S.N., Oben, P.M. and Engome, R.W. (2019) Trace Metals in Groundwater of the South Eastern Piedmont Region of Mount Cameroon: Quantification and Health Risk Assessment. Open Access Library Journal, 6, e5327. https://doi.org/10.4236/oalib.1105327

[3] Verma, R. and Dwivedi, P. (2013) Heavy Metal Water Pollution-A Case Study. Recent Research in Science and Technology, 5, 98-99.

[4] Akoachere, R.A. and Ngwese, Y.M. (2017) Darcy and Apparent Velocities of Groundwater in Phreatic Aquiferous Formations in Kumba-Cameroon: Determined by Use of Trigger-Tube Tracer Test Method in Dug Wells. Journal of Hydrogeology \& Hydrologic Engineering, 6, 1.

[5] Akoachere, R.A. and Ngwese, Y.M. (2016) Saturated Hydraulic Conductivities and High Yield Zones in the Phreatic Aquiferous Formations in Kumba-Cameroon: Determined from Slug-in Tests in Dug Wells. Journal of Hydrogeology \& Hydrologic Engineering, 5, 4.

[6] Ayuk, A.R. and Mesode, N.Y. (2017) Field Steady State Infiltration Rates of Soils in Kumba-Cameroon: Validation of Some Empirical Predictive Infiltration Models and GIS Applications. GeoinforGeostat: An Overview, 5, 1.

[7] Paustenbach, D.J. (2002) Human and Ecological Risk Assessment: Theory and Practice. John Wiley and Sons, New York.

[8] Hu, X., Zhang, Y., Ding, Z.H., Wang, T.J., Lian, H.Z. and Sun, Y.Y. (2012) BioAccessibility and Health Risk of Arsenic and Heavy Metals (Cd, Co, Cr, Cu, Ni, Pb, $\mathrm{Zn}$ and $\mathrm{Mn}$ ) in TSP and PM2. 5 in Nanjing, China. Atmospheric Environment, 57, 146-152. https://doi.org/10.1016/j.atmosenv.2012.04.056

[9] Lushenko, M.A. (2010) A Risk Assessment for Ingestion of Toxic Chemicals in Fish from Imperial Beach. State University, San Diego, CA.

[10] Koki, I.B., Bayero, A.S., Umar, A. and Yosuf, S. (2015) Health Risk Assessment of Heavy Metals in Water, Air, Soil and Fish. African Journal of Pure and Applied 
Chemistry, 9, 204-210.

[11] Kamunda, C., Mathuthu, M. and Madhuku, M. (2016) Health Risk Assessment of Heavy Metals in Soils from Witwatersrand Gold Mining Basin, South Africa. International Journal of Environmental Research and Public Health, 13, 1-11.

[12] Song, D., Zhuang, D., Jiang, D., Fu, J. and Wang, Q. (2015) Integrated Health Risk Assessment of Heavy Metals in Suxian County, South China. International Journal of Environmental Research and Public Health, 12, 7100-7117. https://doi.org/10.3390/ijerph120707100

[13] Kim, E.J., Herrera, J.E., Huggins, D., Braam, J. and Koshowki, S. (2011) Effect of pH on the Concentrations of Lead and Trace Contaminants in Drinking Water: A Combined Batch, Pipe Loop and Sentinel Home Study. Water Research, 45, 2763 2774. https://doi.org/10.1016/j.watres.2011.02.023

[14] Kolluru, R.V., Bartell, S.M., Pitblado, R.M. and Stricoff, R.S. (1996) Risk Assessment and Management Handbook. McGraw-Hill, New York.

[15] Edet, A.E. and Offiong, O.E. (2002) Evaluation of Water Quality Pollution Indices for Heavy Metal Contamination Monitoring, a Study Case from Akpabuyo-Odukpani Area Lower Cross River Basin (Southeastern Nigeria). GeoJournal, 57, 295 304.

[16] Zhang, L.P., Ye, X., Feng, H., et al. (2007) Heavy Metal Contamination in Western Xiamen Bay Sediments and Its Vicinity, China. Marine Pollution Bulletin, 54, 974982. https://doi.org/10.1016/j.marpolbul.2007.02.010

[17] Hakanson, L. (1980) An Ecological Risk Index for Aquatic Pollution Control. A Sedimentological Approach. Water Research, 14, 975-1001.

https://doi.org/10.1016/0043-1354(80)90143-8

[18] Harikumar, P.S., Nasir, U.P. and Rahman, M.M. (2009) Distribution of Heavy Metals in the Core Sediments of a Tropical Wetland System. International Journal of Environmental Science \& Technology, 6, 225-232. https://doi.org/10.1007/BF03327626

[19] Ji, C., Kwon, E., Nga, L., Myung, C., Jung, E., Georges, E., Mbome, L.I. and KiHyun, K. (2012) Impact Assessment of Heavy Metal Pollution in the Municipal Lake Water, Yaounde, Cameroon. Geosciences Journal, 16, 193-202.

[20] WHO (2011) Guidelines for Drinking-Water Quality. 1-541

[21] USEPA (2012) Waste and Clean up Risk Assessment. http://www2.epa.gov/risk/waste-and-cleanup-risk-assessment

[22] Agunbiade, F.O., Olu-Owolabi, B.I. and Adebowale, K.O. (2009) Phytoremediation Potential of Eichornia crassipes in Metal-Contaminated Coastal Water. Bioresource Technology, 100, 4521-4526. https://doi.org/10.1016/j.biortech.2009.04.011

[23] Liaghati, T., Preda, M. and Cox, M. (2003) Heavy Metal Distribution and Controlling Factors within Coastal Plain Sediments, Bells, Creek Catchment, Southeast Queensland, Australia. Environment International, 29, 935-948. https://doi.org/10.1016/S0160-4120(03)00060-6

[24] Adebowale, K.O., Agunbide, F.O. and OluOwolabi, B. (2009) Trace Metal Concentration, Site Variations and Partitioning Pattern in Water and Bottom Sediments from Coastal Area: A Case Study of Ondo Coast, Nigeria. Environmental Research Journal, 3, 46.

[25] Singh, M., Ansari, A.A., Müller, G. and Singh, I.B. (1997) Heavy Metals in Freshly Deposited Sediments of the Gomati River (a Tributary of the Ganga River): Effects of Human Activities. Environmental Geology, 29, 246-252. https://doi.org/10.1007/s002540050123 